\title{
Wear of Polycrystalline Boron Nitride Tool During the Friction Stir Welding of Steel
}

\author{
M. Almoussawi ${ }^{1,2} \cdot$ A. J. Smith ${ }^{2} \cdot$ M. Faraji ${ }^{3}$
}

Received: 26 August 2017 / Revised: 18 February 2018/ Accepted: 10 March 2018 / Published online: 22 May 2018

(C) The Author(s) 2018

\begin{abstract}
The wear issue of a polycrystalline boron nitride (PCBN) tools during the friction stir welding of two grades of steel, DH36 and EH46, was studied. Two welding traverse and tool rotational speeds were used when welding the DH36 steel. A low tool speed (200RPM, $100 \mathrm{~mm} / \mathrm{min}$ ) and a high tool speed (550RPM, $400 \mathrm{~mm} / \mathrm{min}$ ) were denoted by $\mathrm{W}_{1 \mathrm{D}}$ and $\mathrm{W}_{2 \mathrm{D}}$, respectively. Nine welding conditions were applied to the welding of EH46 steel plate including seven plunge/dwell trials $\left(\mathrm{W}_{1 \mathrm{E}}-\mathrm{W}_{7 \mathrm{E}}\right)$ and two steady-state trials $\left(\mathrm{W}_{8 \mathrm{E}}\right.$ and $\left.\mathrm{W}_{9 \mathrm{E}}\right)$. SEM-EDS and XRD tests were applied in order to reveal the boronitride (BN) particles inside the welded joints, and the percentage (\%) of BN was calculated according to the standard quantitative metallographic technique. The findings showed that tool wear increases when the tool rotational speed increases as a result of binder softening which is a function of the peak temperature (exceeds $1250{ }^{\circ} \mathrm{C}$ ) at the tool/workpiece interface. When considering the EH46 steel trials, it was found that an increase in the tool traverse speed in friction stir welding caused a significant tool wear with $4.4 \%$ of $\mathrm{BN}$ in the top of the stirred zone of $\mathrm{W}_{9 \mathrm{E}}$ compared to $1.1 \%$ volume fraction of $\mathrm{BN}$ in $\mathrm{W}_{8 \mathrm{E}}$ which was attributed to the higher thermomechanical action on the PCBN tool surface. Tool wear was also found to increase with an increase in tool plunge depth as a result of the higher contact between the surface of friction stir welding tool and the workpiece.
\end{abstract}

Keywords Friction stir welding $\cdot$ PCBN tool $\cdot$ Wear $\cdot$ DH36 and EH46 steel

\section{Introduction}

Friction stir welding (FSW) is a solid-state welding technique invented at The Welding Institute (TWI) in 1991 [1]. This solid-state process was successfully developed to enable welding of aluminum alloys such as the $2 \mathrm{XXX}$ and 7XXX series which, at that time, were considered unweldable using standard fusion welding processes [1]. However, for welding high melting alloys such as steel, the process is still limited because of the high cost of the FSW tool. For welding low melting alloys such as aluminum, the tool is usually made from a suitable steel grade such as alloy H13 which can be used to produce tools with

\footnotetext{
M. Almoussawi

inj.mun@atu.edu.iq; b1045691@my.shu.ac.uk

Al-Furat Al-Awsat Technical University, Kufa, Iraq

2 MERI, Sheffield Hallam University, S1 1WB Sheffield, UK

3 Coventry University, Coventry, UK
}

complex designs at relatively low costs. Welding high melting alloys requires a FSW tool material with higher thermal and mechanical properties compared to other tools used for low melting point materials. Polycrystalline boron nitride (PCBN) is the most widely used super-abrasive ceramic FSW tool. Table 1 [2] shows the mechanical and thermal properties of a PCBN tool compared to tungsten carbide (WC) and H13 FSW tools. The microhardness of this tool HV (2600-3500) shows that the PCBN tool is the second hardest tool after diamond. It also has a low coefficient of friction which in turn helps in producing smooth weld surfaces [3]. However, a low coefficient of friction in a FSW tool necessitates an increase in tool rotational speed to produce the required heat for welding [4]. The PCBN tool represents an alternative to refractory tools such as tungsten-based materials which showed severe wear, especially during FSW of steel [5]. The PCBN tool usually contains cubic boron nitride (CBN) particles in an aluminum nitride (AIN) binder [6]. This combination between the $\mathrm{CBN}$ and the binder is designed to increase the strength 
Table 1 The physical properties of PCBN compared with some other materials [2]

\begin{tabular}{lllll}
\hline Property & Units & PCBN & Tungsten carbide & 4340 Steel \\
\hline Coefficient of friction & $\ldots$ & $0.10-0.15$ & 0.2 & 0.78 \\
Coefficient of thermal expansion & $10^{-6} /{ }^{\circ} \mathrm{C}$ & $4.6-4.9$ & $4.9-5.1$ & $11.2-14.3$ \\
Thermal conductivity & $\mathrm{W} / \mathrm{mK}$ & $100-250$ & 95 & 48 \\
Compressive strength & $\mathrm{N} / \mathrm{mm}^{2}$ & $2700-3500$ & 6200 & 690 \\
& $10^{3} \mathrm{psi}^{2}$ & $391-507$ & 899 & 100 \\
Fracture toughness & $\mathrm{MPa} \mathrm{\textrm {m } ^ { 2 }}$ & $3.5-6.7$ & 11 & 100 \\
Hardness & $\mathrm{Knoop} \mathrm{kg} / \mathrm{mm}^{2}$ & $2700-3200$ & $\ldots$ & 278 \\
& $\mathrm{Vickers} \mathrm{kg/ \textrm {mm } ^ { 2 }}$ & $2600-3500$ & $1300-1600$ & 280 \\
Tensile strength & $\mathrm{N} / \mathrm{mm}^{2}$ & $\ldots$ & 1100 & 620 \\
& $10^{3} \mathrm{psi}^{2}$ & $\ldots$ & 160 & 89.9 \\
Transverse & $\mathrm{N} / \mathrm{mm}^{2}$ & $500-800$ & 2200 & $\ldots$ \\
Rupture strength & $10^{3} \mathrm{psi}$ & $72-115$ & 319 & $\ldots$ \\
\hline
\end{tabular}

of the tool. Despite the high strength and thermal properties, the PCBN tool has low fracture toughness and is also susceptible to wear problems, especially during the plunge period of the weld due to the higher temperature generated which can cause a softening of the binder [3]. The plunge period is also associated with a high plunge force which can encourage BN particles to detach from the tool and stick into the workpiece. The development in metal-composite material has encouraged manufacturers such as MegaStir $\odot$ to produce new grades of PCBN tools with a longer service life. This development was a step forward in order to commercialize the FSW of high melting alloys. For example, a FSW tool made from Q70 (70\%PCBN, $30 \% \mathrm{WRe}$ ) has a higher toughness compared to the previous one which included an AlN binder [6]. The melting point of a Q70 tool PCBN material was determined to exceed $3000{ }^{\circ} \mathrm{C}$, and the microstructure and tool image are shown in Fig. 1a and b, respectively [6]. The Q70 tool has been used extensively by TWI to join many steel grades including 316L stainless steel, 304 stainless steel, and DH36 and EH46 steel grades which are under consideration in this work. PCBN-WRe Q70 tool as shown in Fig. 1b consists of a shoulder and probe surrounded by a collar of a $\mathrm{Ni}-\mathrm{Cr}$ alloy which works as an insulator for the tool from the environment, so the heat generated during the FSW is almost distributed between the PCBN tool and the workpiece. The PCBN tool is also attached to a shank made of WC which acts as a holder and attaches the tool to the PowerStir FSW machine. Both parts of the tool, including the PCBN material and WC shank, are fastened together by a collar. The different parts of the PCBN tool geometry are listed in Table 2 which is according to the workpiece thickness (6 and $14 \mathrm{~mm}$ ). Welding a 6-mmthick specimen is usually carried out using a PCBN tool with $5.5-\mathrm{mm}$ probe length, while for 14-mm-thick specimen a probe length of $12 \mathrm{~mm}$ is usually used. The PowerStir FSW machine includes a cooling system applied to the tool shank in order to reduce the temperature resulting from the friction stir welding of steel which is readily transmitted due to the high thermal conductivity of the PCBN tool. Argon shielding is usually applied during the FSW process mainly to extend the tool life and also to prevent oxidation of the welded joint. A thermocouple is usually attached to the tool shank and is located behind the PCBN tool. This telemetry system is employed to monitor tool temperature during the FSW process. The FSW tool manufacturer recommends that the temperature of the tool measured by the telemetry thermocouples system should be kept in the range of $800-900{ }^{\circ} \mathrm{C}$ in order to protect the tool from excessive wear/breakage issues [5]. Other tool materials and their properties which have been used for high melting alloys are usually made of refractory
Fig. 1 (a) An SEM image of the microstructure of a cross section through a PCBN Q70 (70\% cBN, 30\%WRe) [6] FSW tool, (b) PCBN tool image

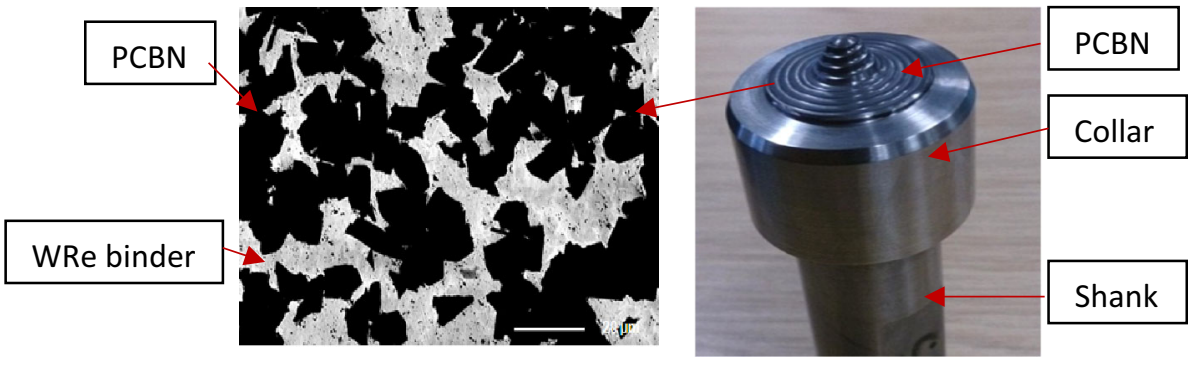

a 
Table 2 PCBN tool geometry provided by TWI

\begin{tabular}{|c|c|c|c|c|}
\hline Tool & PCBN shoulder & PCBN probe & Collar & Shank \\
\hline $\begin{array}{l}\text { PCBN tool geometry for welding } \\
6 \mathrm{~mm} \text { thickness }\end{array}$ & $\begin{array}{l}23.7 \mathrm{~mm} \text { diameter with spiral } \\
\text { convex shape }\end{array}$ & $\begin{array}{l}5.5 \mathrm{~mm} \text { length, } 10 \mathrm{~mm} \text { base } \\
\text { diameter } \\
\text { Spiral tapered with } 20 \text { thread } \\
\text { per inch (TPI) }\end{array}$ & $\begin{array}{l}23.9 \mathrm{~mm} \text { inner } \\
\text { diameter } \\
37 \text { mm outer } \\
\text { diameter } \\
24 \text { mm length }\end{array}$ & $\begin{array}{l}23.9 \mathrm{~mm} \text { diameter } \\
80.35 \mathrm{~mm} \text { length }\end{array}$ \\
\hline $\begin{array}{l}\text { PCBN tool geometry for welding } \\
10-15 \mathrm{~mm} \text { thickness }\end{array}$ & $\begin{array}{l}38 \mathrm{~mm} \text { mm diameter with } \\
\text { spiral convex shape }\end{array}$ & $\begin{array}{l}12 \mathrm{~mm} \text { length, } 20 \mathrm{~mm} \text { base } \\
\text { diameter } \\
\text { Spiral tapered with } 20 \text { thread } \\
\text { per inch (TPI) }\end{array}$ & $\begin{array}{l}38.1 \mathrm{~mm} \text { inner } \\
\text { diameter } \\
52 \mathrm{~mm} \text { outer } \\
\text { diameter } \\
30 \mathrm{~mm} \text { length }\end{array}$ & $\begin{array}{l}38.1 \mathrm{~mm} \text { diameter } \\
100 \mathrm{~mm} \text { length }\end{array}$ \\
\hline
\end{tabular}

materials based on tungsten such as WC, W-Re, W-Co and can be found in the literature [3,7]. This paper will focus only on the PCBN tool wear as this is the tool which has been employed to produce the samples under study.

Wear resistance in hybrid PCBN FSW tools is considered better than other refractory materials such as tungstenbased tools. W-25\%Re FSW tool life of $4 \mathrm{~m}$ was reported in welding steel grades and titanium [7]. However, wear issues still exist in PCBN tools when welding high melting alloys especially the high strength alloys such as the EH46 steel grade. An experimental study of a PCBN tool has been carried out by Rai et al. [3] and showed that the main factors which can cause wear are abrasion and diffusion. Softening and recrystallization of the binder after reaching a welding temperature of $1000{ }^{\circ} \mathrm{C}$ is also found to be one reason for reducing the tools resistance to wear [3]. Ramalingam and Jacobson [8] reported a decrease in Knoop hardness (HK) of W-25Re from HK 675 (HV 638) to HK 500 (HV 478) when carrying out heating from room temperature to $1225{ }^{\circ} \mathrm{C}$. The hardness was found to decrease dramatically to HK 300 (HV 290) when the temperature increases to $1450{ }^{\circ} \mathrm{C}$. Hooper et al. [9] suggested that the higher thermal conductivity of cBN $(100-250 \mathrm{~W} / \mathrm{m} \mathrm{K})$ can result in defects in the microstructure when the temperature exceeds $1200 \mathrm{~K}$, while with a comparison with $\mathrm{cBN}-\mathrm{TiC}$, they found that a protective layer (mainly $\mathrm{TiC}$ ) is formed on the latter and is associated with the higher temperature as a result of lower thermal conductivity of cBN-TiC. PCBN tool wear can also change the properties of the material being welded. For example tool wear can affect negatively a stainless steel welded joint as boron particles can react with $\mathrm{Cr}$ to form borides which in turn can result in a reduction in corrosion resistance [3]. When welding titanium plates, boron can improve the mechanical properties of the joint because of the ability to react with $\mathrm{Ti}$-forming $\mathrm{TiB}_{2}$ which in turn can cause grain refinement and a hardness increase [10]. PCBN tool breakage is more likely to occur during the FSW process due to the lower fracture toughness of a PCBN tool compared to a WC tool, Table 1. Unsuitable welding parameters such as improper plunging or extracting and low welding temperatures were determined as the main factors for tool breakage [5].

Previous work on PCBN tool wear during the friction stir welding of steel did not investigate the possibility of W-Re binder softening as a result of high temperature which may reach the local melting of steel alloys during the process, especially when the tool rotational speed reaches specific limits. Also limited work has been carried out to investigate the effect of tool traverse speed on the wear rate and the consequences on the physical properties of the welded joints. The current work focuses on PCBN tool wear which occurs during the FSW process of two steel grades, DH36 and EH46. The FSW tool wear has been studied by calculating the volume fraction of BN (originally from the PCBN FSW tool) existed in the thermomechanical affected zone (TMAZ) microstructure. The aims are to identify the causes of PCBN tool wear and to highlight the different suitable welding parameters that can increase the tool longevity.

\section{Experimental Method}

\section{Chemical Composition of Parent Metal and Welding Conditions}

Tables 3 and 4 show the as-received chemical composition (wt.\%) of the 6-mm-thick DH36 and 14-mm-thick EH46 steel plates. The welded samples have been produced at
Table 3 Chemical composition of as-received DH36 steel grade (wt.\%)

\begin{tabular}{llllllllllllll}
\hline $\mathrm{C}$ & $\mathrm{Si}$ & $\mathrm{Mn}$ & $\mathrm{P}$ & $\mathrm{S}$ & $\mathrm{Al}$ & $\mathrm{N}$ & $\mathrm{Nb}$ & $\mathrm{V}$ & $\mathrm{Ti}$ & $\mathrm{Cu}$ & $\mathrm{Cr}$ & $\mathrm{Ni}$ & $\mathrm{Mo}$ \\
\hline 0.16 & 0.15 & 1.2 & 0.01 & 0.005 & 0.043 & 0.02 & 0.02 & 0.002 & 0.001 & 0.029 & 0.015 & 0.014 & 0.002 \\
\hline
\end{tabular}


Table 4 Chemical composition of as-received EH46 steel grade (wt.\%)

\begin{tabular}{llllllllll}
\hline $\mathrm{C}$ & $\mathrm{Si}$ & $\mathrm{Mn}$ & $\mathrm{P}$ & $\mathrm{S}$ & $\mathrm{Al}$ & $\mathrm{N}$ & $\mathrm{Nb}$ & $\mathrm{V}$ & $\mathrm{Ti}$ \\
\hline 0.20 & 0.55 & 1.7 & 0.03 & 0.03 & 0.015 & 0.02 & 0.03 & 0.1 & 0.02
\end{tabular}

TWI/Yorkshire using their PowerStir ${ }^{\mathrm{TM}}$ FSW machine, employing a Q70 PCBN FSW tool. The welding conditions used for the production of samples of DH36 steel ( $\mathrm{W}_{1 \mathrm{D}}$ and $\mathrm{W}_{2 \mathrm{D}}$ ) are shown in Table 5. These were chosen to examine the effect of tool rotational and traverse speeds on tool wear. In order to examine tool traverse speeds above $200 \mathrm{~mm} / \mathrm{min}$, it is necessary to simultaneously increase the tool rotational speed. The welding conditions for the production of samples of EH46 steel $\left(\mathrm{W}_{1 \mathrm{E}}-\mathrm{W}_{7 \mathrm{E}}\right)$ which examined the effect of rotational speed and plunge depth on tool wear are shown in Table 6. The welding process parameters used to examine the effect of tool traverse speed on tool wear $\left(\mathrm{W}_{8 \mathrm{E}}\right.$ and $\left.\mathrm{W}_{9 \mathrm{E}}\right)$ for $\mathrm{EH} 46$ steel steady state are shown in Table 7.

\section{Scanning Electron Microscopy (SEM) and Energy- Dispersive X-ray Spectroscopy (EDS) Examination}

SEM and EDS were carried out on polished (until $1 \mu \mathrm{m}$ ) and etched (2\% nital) FSW samples using the FEI Nova Nano SEM. The examination included the surface of the stirred zone (SZ) and thermomechanical affected zone (TMAZ) which are the regions which experienced both thermal and mechanical effects during the FSW process under steady-state conditions and at the plunge period. The SEM produced high-quality and high-resolution images of microconstituents using the secondary electron (SE) imaging mode with an accelerating voltage of between 10 and $20 \mathrm{kV}$. The working distance (WD) used was $5 \mathrm{~mm}$, but in some cases, it was altered (decreased or increased) to enhance the contrast at higher magnification. EDS-SEM examination was mainly used to detect the $\mathrm{BN}$ particle

Table 5 Welding conditions for FSW DH36 steel samples $\mathrm{W}_{1 \mathrm{D}}$ and $\mathrm{W}_{2 \mathrm{D}}$

\begin{tabular}{|c|c|c|c|c|c|c|c|c|}
\hline $\begin{array}{l}\text { Weld } \\
\text { no. }\end{array}$ & $\begin{array}{l}\text { Tool rotational } \\
\text { speed }(\omega) \text { RPM }\end{array}$ & $\begin{array}{l}\text { Traverse } \\
\text { speed } \\
\text { (V) } \mathrm{mm} / \mathrm{min}\end{array}$ & $\begin{array}{l}\text { Rotational/traverse } \\
\text { speeds (rev/mm) }\end{array}$ & $\begin{array}{l}\text { Average } \\
\text { spindle torque } \\
\mathrm{N} \mathrm{m}\end{array}$ & $\begin{array}{l}\text { Average tool } \\
\text { torque } \mathrm{N} \mathrm{m}\end{array}$ & $\begin{array}{l}\text { Axial force } \\
\text { (average) } \\
\text { KN }\end{array}$ & $\begin{array}{l}\text { Longitudinal } \\
\text { force (average) } \\
\text { KN }\end{array}$ & $\begin{array}{l}\text { Heat input } \\
\left(\frac{\omega \times \text { torque }}{V}\right)\end{array}$ \\
\hline $\mathrm{W}_{1 \mathrm{D}}$ & 200 & 100 & 2 & 278 & 105 & 57.55 & 12.8 & 210 \\
\hline $\mathrm{W}_{2 \mathrm{D}}$ & 550 & 400 & 1.375 & 163 & 62 & 47 & 12 & 64.625 \\
\hline
\end{tabular}

Table 6 The welding conditions for FSW EH46 steel to examine the effect of rotational speed and actual plunge depth on tool wear $\left(\mathrm{W}_{1 \mathrm{E}^{-}}-\mathrm{W}_{7 \mathrm{E}}\right)$

\begin{tabular}{lllllll}
\hline $\begin{array}{l}\text { Weld } \\
\text { trial no. }\end{array}$ & $\begin{array}{l}\text { Tool rotational speed } \omega \\
(\mathrm{RPM}) \text { at dwell period }\end{array}$ & $\begin{array}{l}\text { Max. axial (plunge) } \\
\text { force }\left(F_{z}\right) \mathrm{KN}\end{array}$ & $\begin{array}{l}\text { Max. longitudinal } \\
\text { force }\left(F_{x}\right) \mathrm{KN}\end{array}$ & $\begin{array}{l}\text { Max. torque } \\
(\mathrm{M}) \mathrm{N} \mathrm{m}\end{array}$ & $\begin{array}{l}\text { Plunge depth }(\mathrm{Z}) \mathrm{mm} \\
\text { from FSW machine }\end{array}$ & $\begin{array}{l}\text { Dwell time (t) sec at } \\
(\mathrm{dwell}) \text { period }\end{array}$ \\
\hline $\mathrm{W}_{1 \mathrm{E}}$ & 200 & 157 & 17 & 498 & 13 & 6 \\
$\mathrm{~W}_{2 \mathrm{E}}$ & 200 & 127 & 17 & 471 & 13 & 8 \\
$\mathrm{~W}_{3 \mathrm{E}}$ & 120 & 116 & 21 & 598 & 13 & 7 \\
$\mathrm{~W}_{4 \mathrm{E}}$ & 120 & 126 & 20 & 549 & 13 & 6 \\
$\mathrm{~W}_{5 \mathrm{E}}$ & 120 & 115 & 17 & 532 & 13 & 7 \\
$\mathrm{~W}_{6 \mathrm{E}}$ & 120 & 105 & 18 & 583 & 13 & 7 \\
$\mathrm{~W}_{7 \mathrm{E}}$ & 120 & 119 & 20 & 548 & 13 & 7 \\
\hline
\end{tabular}

Table 7 Welding conditions for FSW EH46 steel during steady-state welding ( $\mathrm{W}_{8 \mathrm{E}}$ and $\mathrm{W}_{9 \mathrm{E}}$ )

\begin{tabular}{llllllll}
\hline $\begin{array}{l}\text { Weld } \\
\text { no. }\end{array}$ & $\begin{array}{l}\text { Tool } \\
\text { rotational } \\
\text { speed RPM }\end{array}$ & $\begin{array}{l}\text { Traverse } \\
\text { speed } \mathrm{mm} / \\
\text { min }\end{array}$ & $\begin{array}{l}\text { Rotational/traverse } \\
\text { speeds }\end{array}$ & $\begin{array}{l}\text { Average } \\
\text { spindle torque } \\
\mathrm{N} \mathrm{m}\end{array}$ & $\begin{array}{l}\text { Average tool } \\
\text { torque N m }\end{array}$ & $\begin{array}{l}\text { Axial force } \\
\text { (average) KN }\end{array}$ & $\begin{array}{l}\text { Longitudinal } \\
\text { force }(\text { average }) \\
\mathrm{KN}\end{array}$ \\
\hline $\mathrm{W}_{8 \mathrm{E}}$ & 150 & 50 & 3 & 300 & 114 & 6 & $\begin{array}{l}\text { Heat input } \\
\left(\frac{\omega \times \text { torque }}{V}\right)\end{array}$ \\
$\mathrm{W}_{9 \mathrm{E}}$ & 150 & 100 & 1.5 & 450 & 171 & 72 & 13 \\
\hline
\end{tabular}

Examining the effect of traverse speed on tool wear 
inside the TMAZ. Spot analysis (point and ID) has been employed to elementally identify small second-phase particles in the scanned SEM images. Additionally, EDS mapping was used to analyze the whole scanned SEM area.

\section{X-ray Diffraction}

X-ray diffraction ( $\mathrm{Cu}$ X-ray tube) using the Empyrean Philips XRD has been carried out on the FSW samples for the following reasons:

- To reveal and characterize the as-received sample phases in order to allow for the detection of any phase changes in the steel following FSWing.

- To detect other additional phases, elements, and/or boronitride (BN) particles which may appear in the welded joints.

\section{Infinite Focus Microscopy (IFM)}

The infinite focus microscopy (IFM) (Alicona) has been employed to create accurate optical light microscopy images of the welded joint. The IFM is a device based on optical 3-dimensional measurements which has the ability to vary the focus in order to obtain a 3D vertical scanned image of the surface. The scanned area of interest can be transferred into a 3D image by the aid of Lyceum software; thus, the surface area can be calculated accurately.

\section{Calculating the Percentage (\%) of BN in the Welded Joints}

The $\%$ of BN particles originating from the PCBN FSW tool in the TMAZ of the welded joints were calculated using the SEM. A $1 \mathrm{~mm}^{2}$ area between the shoulder and the probe side $\left(\mathrm{W}_{1 \mathrm{E}}-\mathrm{W}_{7 \mathrm{E}}\right)$ and a square $\mathrm{mm}\left(1 \mathrm{~mm}^{2}\right)$ from the middle top of

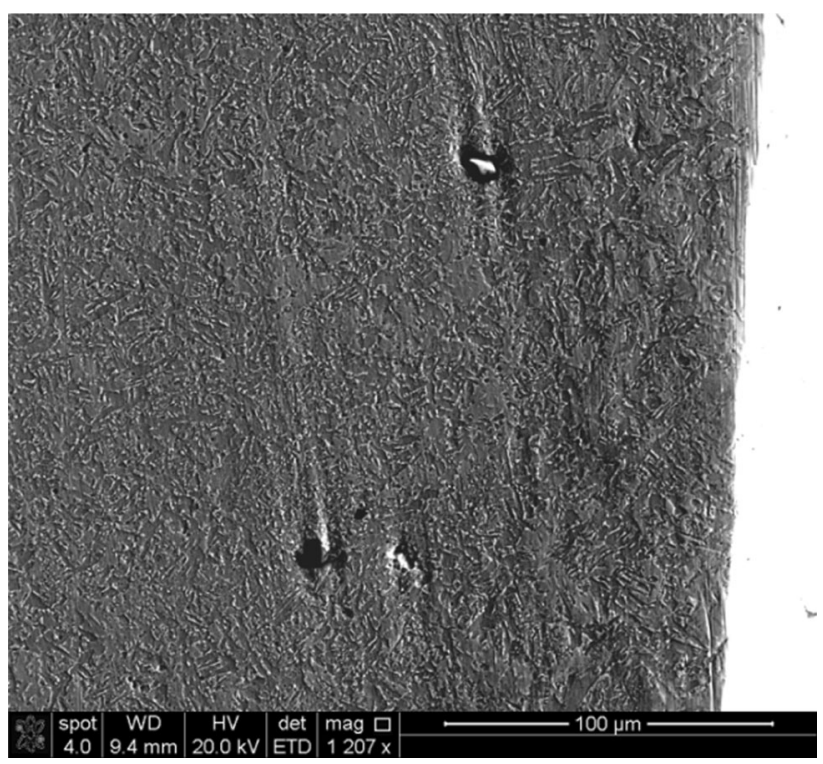

Fig. 3 SEM image of the top of SZ of DH36 $\mathrm{W}_{2 \mathrm{D}}$ shows the existence of $\mathrm{BN}$

the $\mathrm{SZ}$ of sample $\mathrm{W}_{8 \mathrm{E}}$ and $\mathrm{W}_{9 \mathrm{E}}$ were scanned at a maximum magnification of $10,000 \times$. The area fraction of $\mathrm{BN}$ particles and TiN precipitates has been measured manually using the square grid method. The number of intersections of the grid falling in the $\mathrm{BN}$ particles is counted and compared with the total number of points laid down [11].

\section{Result}

\section{Effect of Tool Rotation and Traverse Speed on Tool Wear in FSW of DH36 Steel: Samples $W_{1 D}$ and $W_{2 D}$}

The existence of BN particles originating from the PCBN FSW tool was investigated in the FSW joints of grade
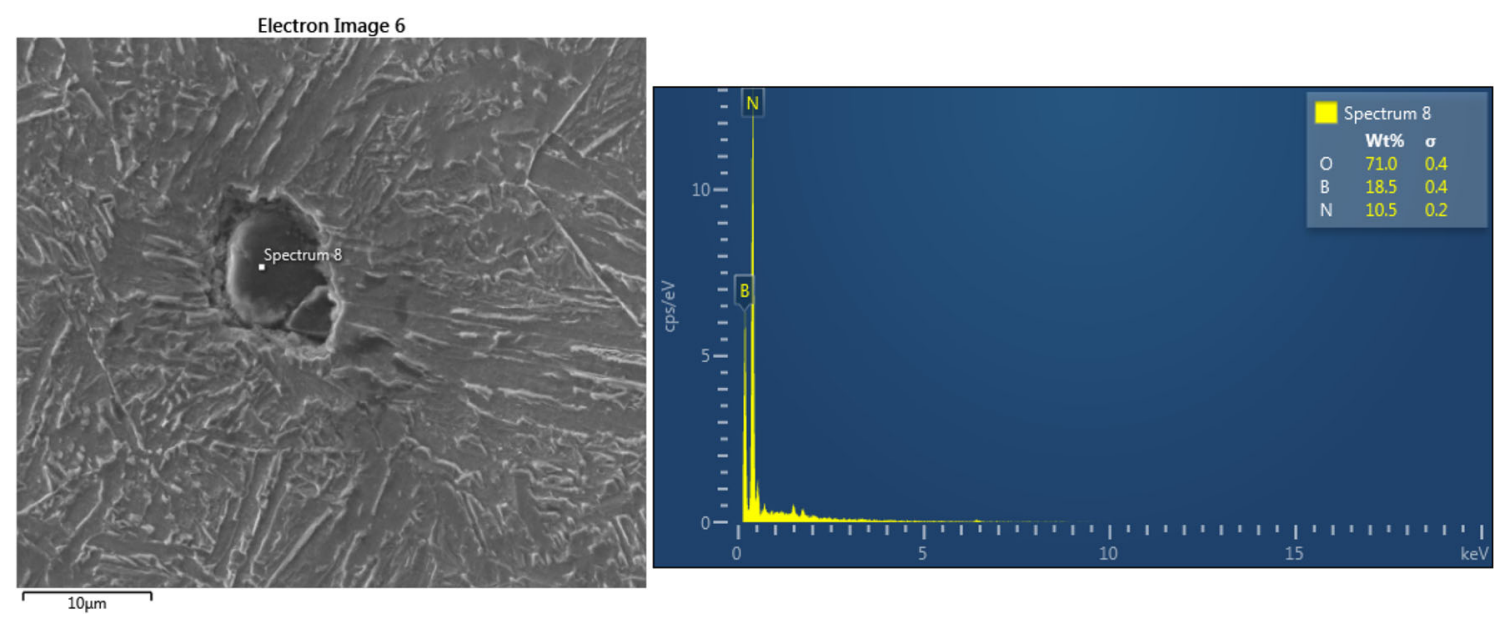

Fig. 2 Ten-micrometer BN particles in SZ of FSW DH36 joint ( $\left.\mathrm{W}_{2 \mathrm{D}} 550 \mathrm{RPM}, 400 \mathrm{~mm} / \mathrm{min}\right)$ 

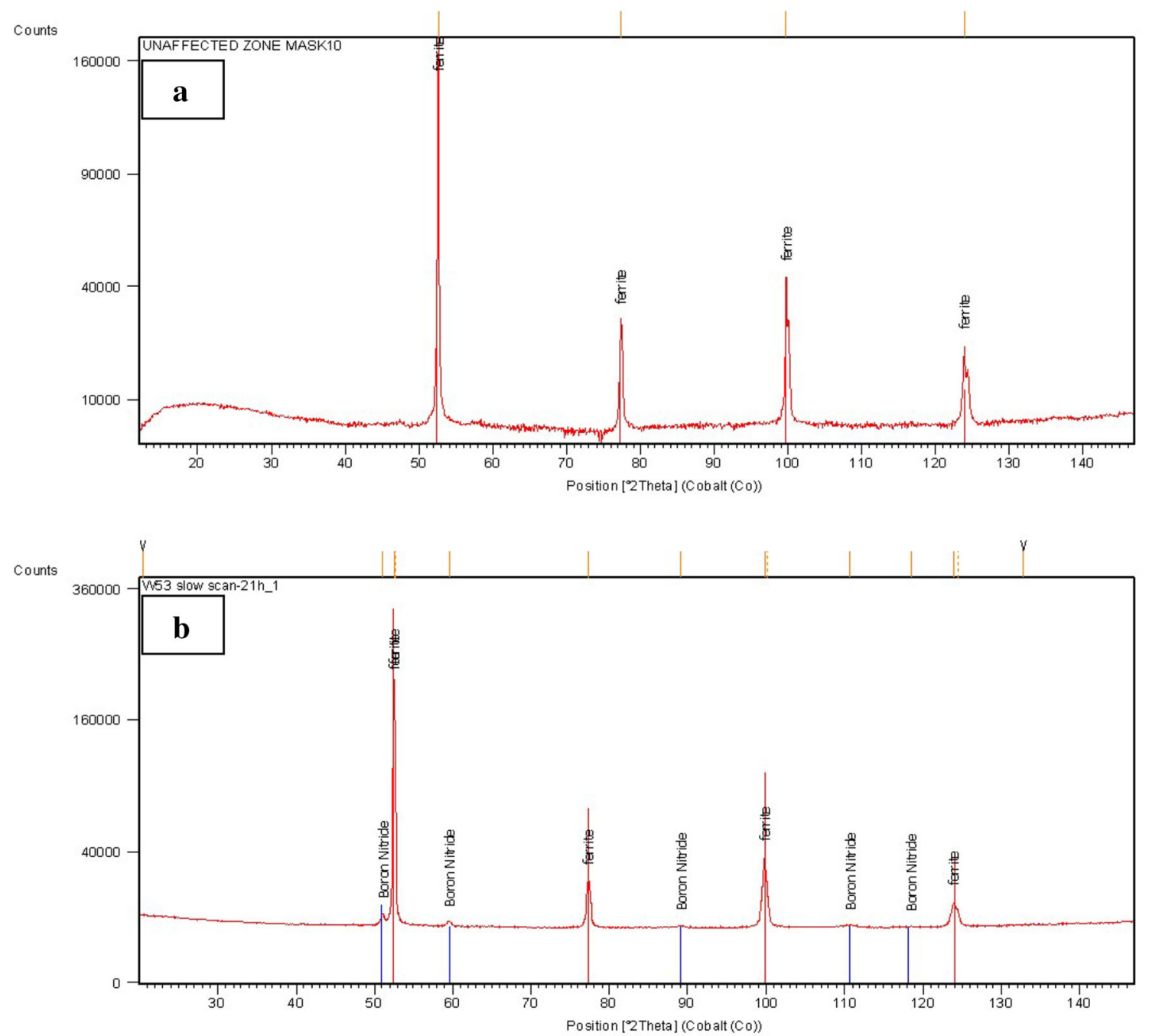

Fig. 4 XRD scan of FSW of DH36 steel (a) $\mathrm{W}_{1 \mathrm{D}}(200 \mathrm{RPM}, 100 \mathrm{~mm} / \mathrm{min}$ ) microstructure consists of BCC ferrite after the FSW process. (b) W (550RPM, $400 \mathrm{~mm} / \mathrm{min}$ ), microstructure is mainly ferritic BCC phase; BN peaks are also present (Co-X-ray tube)

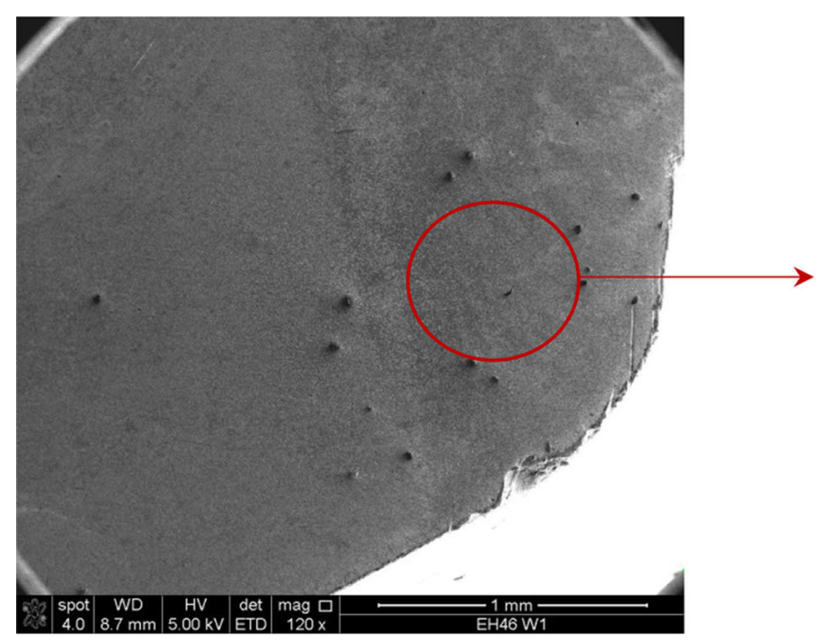

a

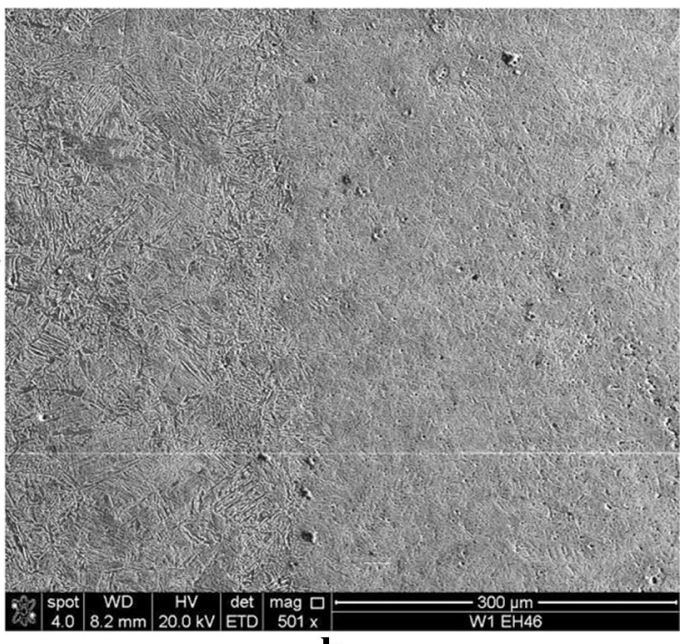

b

Fig. 5 SEM images of EH46 ( $\left.\mathrm{W}_{1 \mathrm{E}}\right)$ at plunge/dwell period showing BN particles (dark spots) with sizes ranging from 0.5 to $13 \mu \mathrm{m}$. (a) Low magnification (region under tool shoulder) and (b) high magnification 
DH36 steel which had been produced at high tool speeds in order to attempt to assess tool wear. SEM-EDS examination of FSW joint $\mathrm{W}_{2 \mathrm{D}}$ (DH36, 550RPM, $400 \mathrm{~mm} / \mathrm{min}$ ) in Figs. 2 and 3 shows different sizes of BN particles in the $\mathrm{SZ}$. Figure $4 \mathrm{a}$ and $\mathrm{b}$ shows the XRD scan results from samples $\mathrm{W}_{1 \mathrm{D}}$ and $\mathrm{W}_{2 \mathrm{D}}$, respectively. Note that peaks of ferrite are shown in both welds and $\mathrm{BN}$ peaks are seen in sample $\mathrm{W}_{2 \mathrm{D}}$. The low tool speed welded joint of DH36 $\mathrm{W}_{1 \mathrm{D}}(200 \mathrm{RPM}, 100 \mathrm{~mm} / \mathrm{min})$ did not show a significant presence of $\mathrm{BN}$ particles in the microstructure.

\section{Effect of Tool Rotational Speed and Actual Plunge Depth on Tool Wear in FSW EH46 Steel: Samples $W_{1 E}-W_{7 E}$}

The presence of BN particles has been investigated in the microstructure of FSW samples of EH46 weld joints during the plunge/dwell period in the shoulder-probe region. The shoulder-probe region is believed to experience the highest material flowing due to the thermomechanical combination of both the shoulder and the probe tool parts. Figures 5, 6,

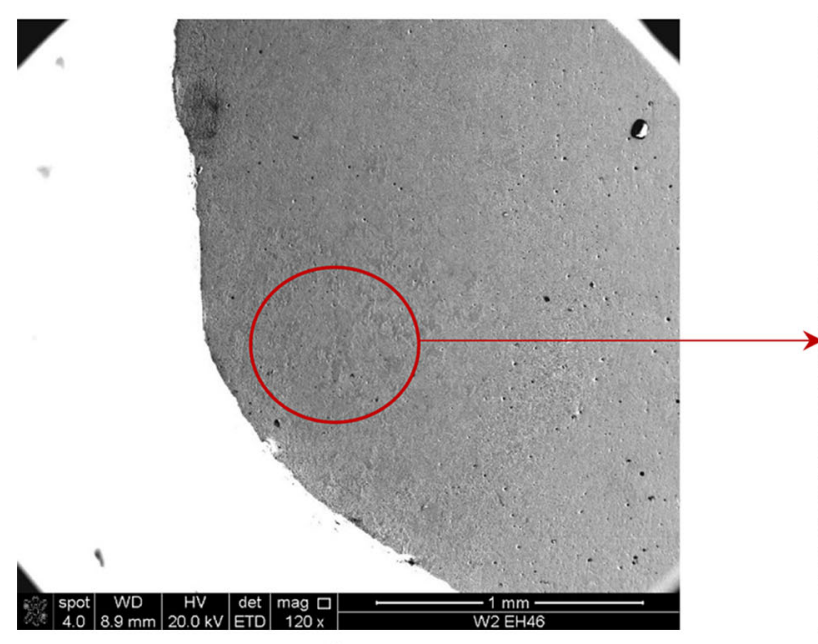

$\mathbf{a}$

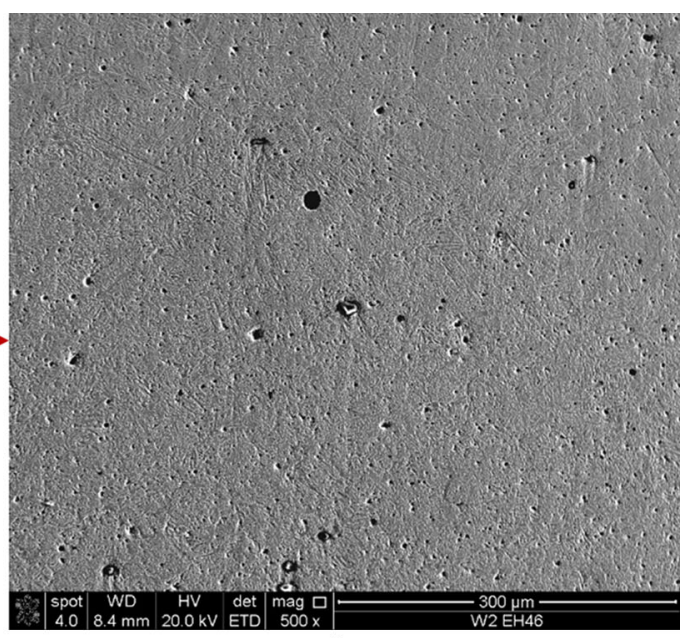

b

Fig. 6 SEM images of EH46 $\left(\mathrm{W}_{2 \mathrm{E}}\right)$ at plunge/dwell period showing BN particles (dark spots) with sizes ranging from 0.5 to $13 \mu \mathrm{m}$. (a) Low magnification (region under tool shoulder) and (b) high magnification

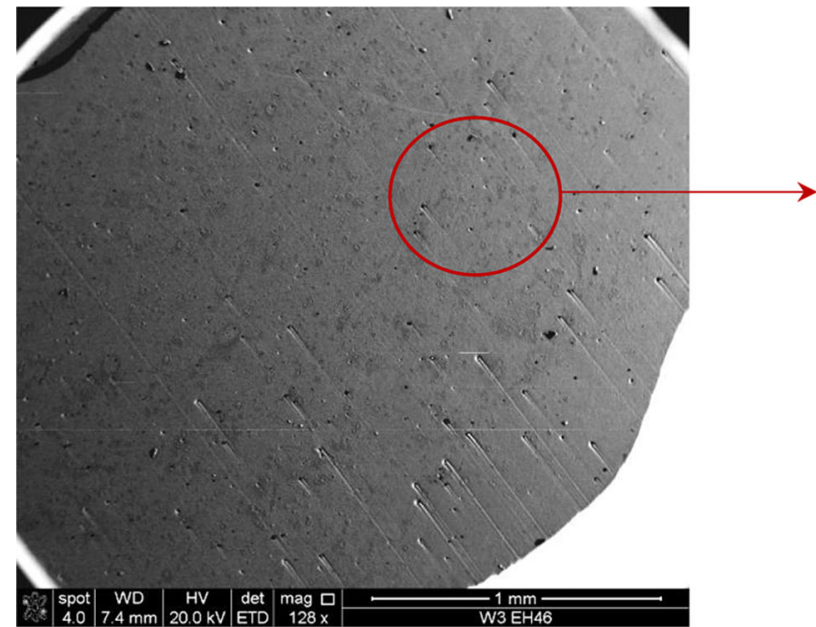

a

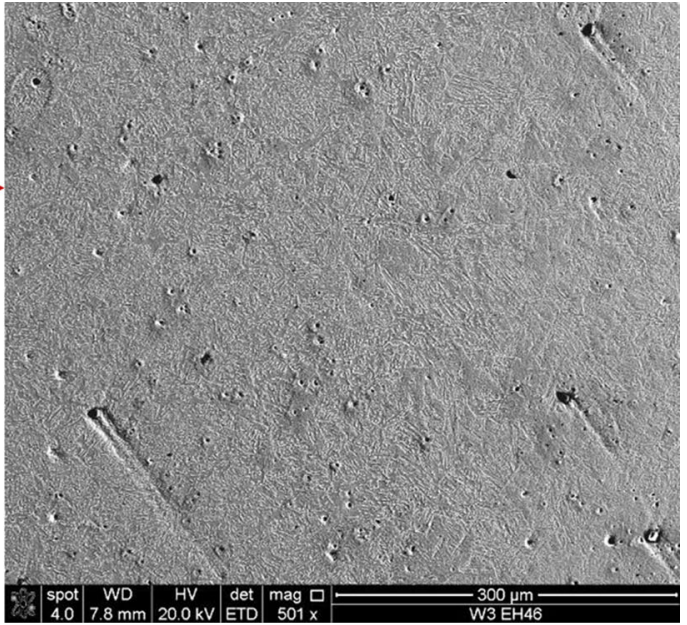

b

Fig. 7 SEM images of EH46 $\left(\mathrm{W}_{3 \mathrm{E}}\right)$ at plunge/dwell period showing BN particles (dark spots) with sizes ranging from 0.5 to $13 \mu \mathrm{m}$. (a) Low magnification (region under tool shoulder) and (b) high magnification 


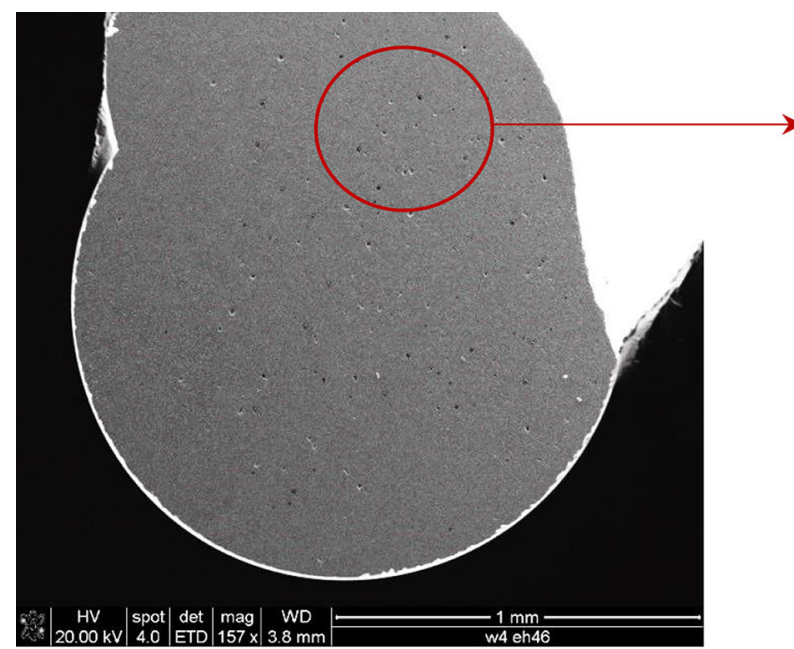

$\mathbf{a}$

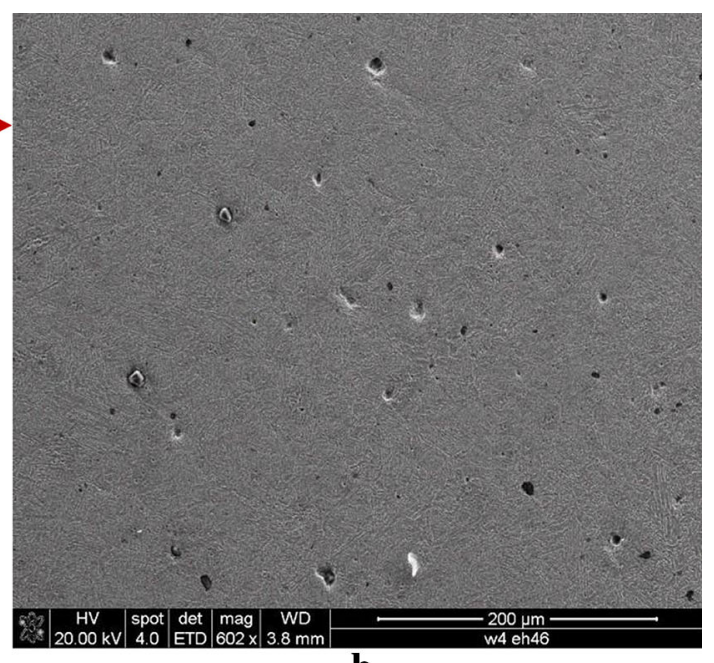

b

Fig. 8 SEM images of EH46 ( $\left.\mathrm{W}_{4 \mathrm{E}}\right)$ at plunge/dwell period showing BN particles (dark spots) with sizes ranging from 0.5 to $13 \mu \mathrm{m}$. (a) Low magnification (region under tool shoulder) and (b) high magnification

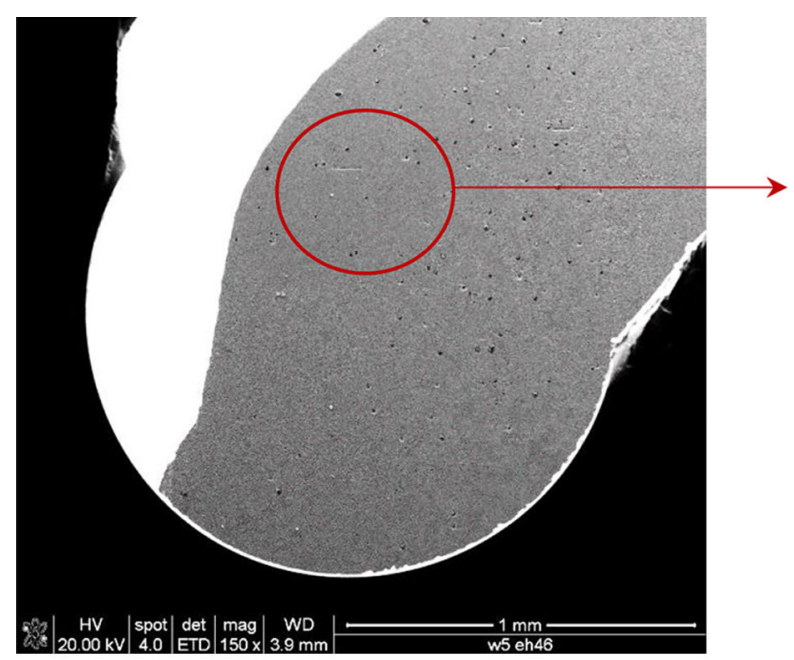

$\mathbf{a}$

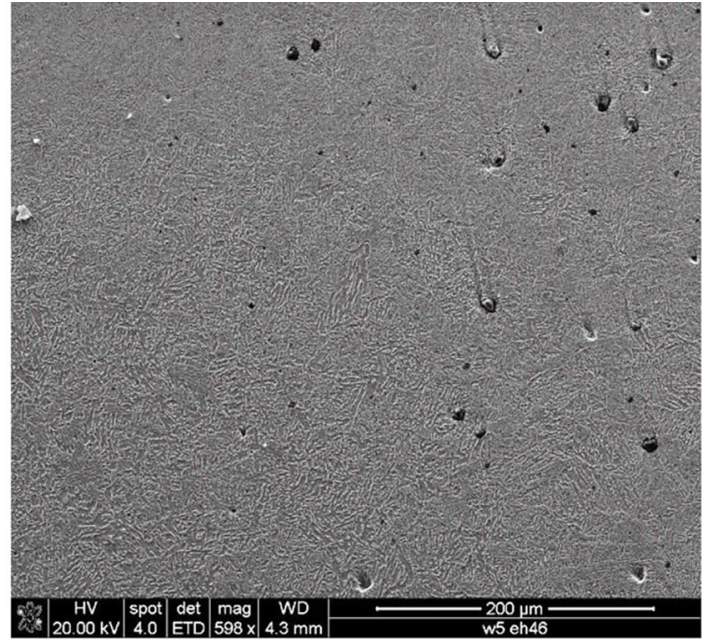

b

Fig. 9 SEM images of EH46 $\left(\mathrm{W}_{5 \mathrm{E}}\right)$ at plunge/dwell period showing BN particles (dark spots) with sizes ranging from 0.5 to $13 \mu \mathrm{m}$. (a) Low magnification (region under tool shoulder) and (b) high magnification

7, 8, 9, 10, and 11 are SEM images (low and high magnification) of samples $\mathrm{W}_{1 \mathrm{E}}-\mathrm{W}_{7 \mathrm{E}}$ (plunge/dwell cases of EH46 grade steel), respectively, which show different sizes and volume fraction of $\mathrm{BN}$ particles. Figure $12 \mathrm{a}$ and $\mathrm{b}$ shows the BN particles at the probe side bottom (region-2 bottom) of samples $\mathrm{W}_{2 \mathrm{E}}$ and $\mathrm{W}_{6 \mathrm{E}}$ (EH46 plunge/dwell period), respectively. Figure 13 shows the XRD scans taken of samples $\mathrm{W}_{1 \mathrm{E}}-\mathrm{W}_{7 \mathrm{E}}$; peaks of ferrite and $\mathrm{BN}$ can be recognized. Table 8 shows the IFM measurements of plunge depth and areas of affected zones of samples $\mathrm{W}_{1 \mathrm{E}^{-}}$ $\mathrm{W}_{7 \mathrm{E}}$ (EH46 steel). Table 9 shows the calculated percentage (\%) area fraction of $\mathrm{BN}$ particles in a $1 \mathrm{~mm}^{2}$ scanned microstructure of the shoulder-probe region [11].

\section{Tool Wear in FSW EH46 Steel for Samples $W_{8 E}$ and $W_{9 E}$ FSW Under Steady-State Conditions}

PCBN tool wear in samples $\mathrm{W}_{8 \mathrm{E}}$ and $\mathrm{W}_{9 \mathrm{E}}(\mathrm{EH} 46)$ steady state has also studied by revealing the $\mathrm{BN}$ particles in the microstructure in order to understand the effect of tool rotational/traverse speeds on the wear issue. Figure 14 is a high magnified SEM image showing a $13-\mu \mathrm{m}$ BN particle found in the $\mathrm{SZ}$ of $\mathrm{W}_{8 \mathrm{E}}$; the binder of $\mathrm{W}$-Re is also shown (the darker phase). Figures 15 and 16 show the SEM-EDS scanning (point and ID technique) of BN of FSW $\mathrm{W}_{8 \mathrm{E}}$ at the top surface of the SZ and at the probe end, respectively. Figures 17 and 18 show the SEM-EDS of BN in the SZ of 


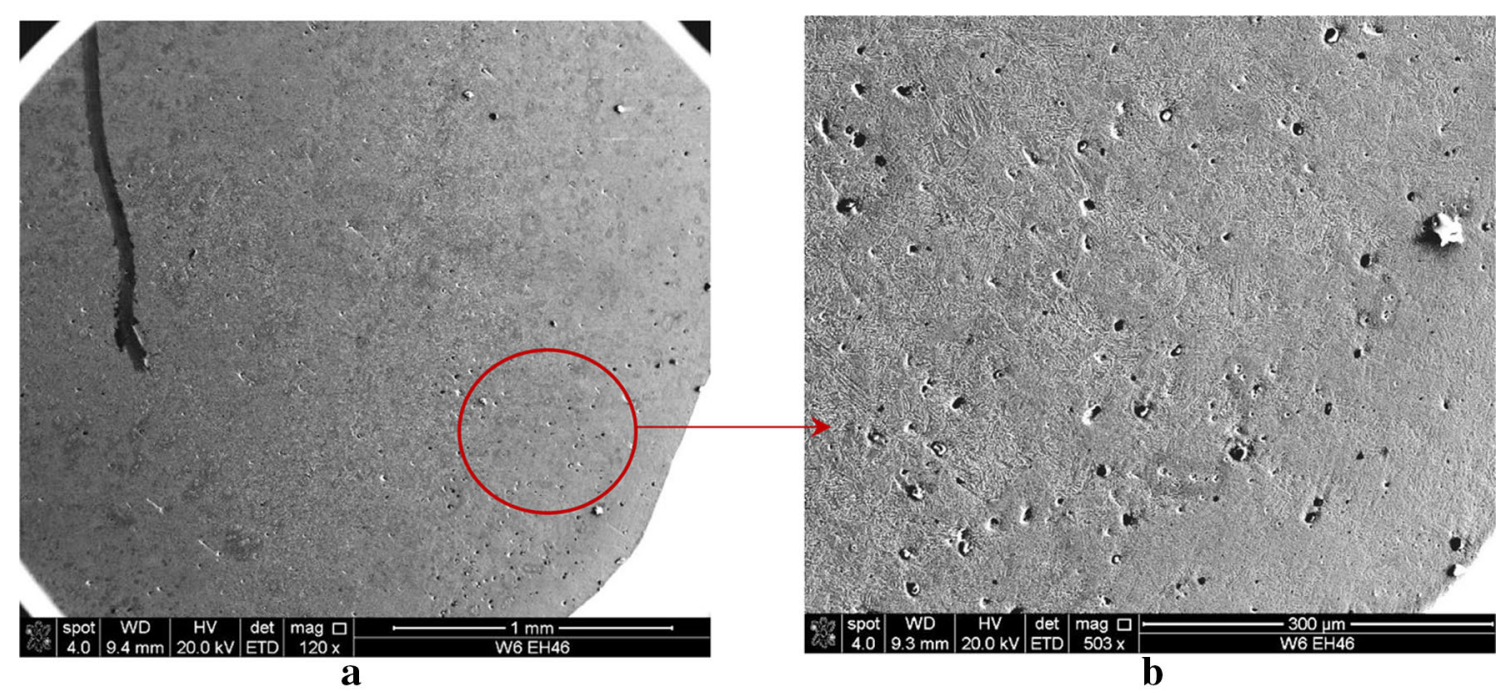

Fig. 10 SEM images of EH46 ( $\left.\mathrm{W}_{6 \mathrm{E}}\right)$ at plunge/dwell period showing BN particles (dark spots) with sizes ranging from 0.5 to $13 \mu \mathrm{m}$. (a) Low magnification (region under tool shoulder) and (b) high magnification

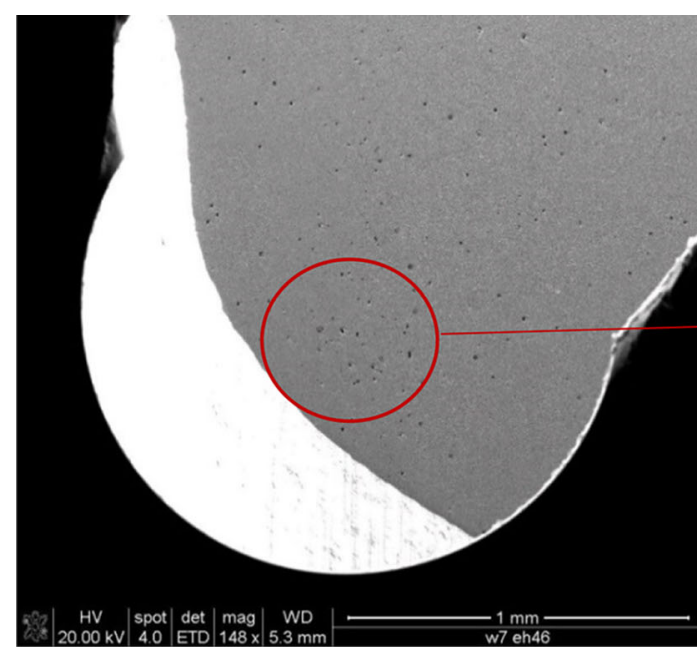

$\mathbf{a}$

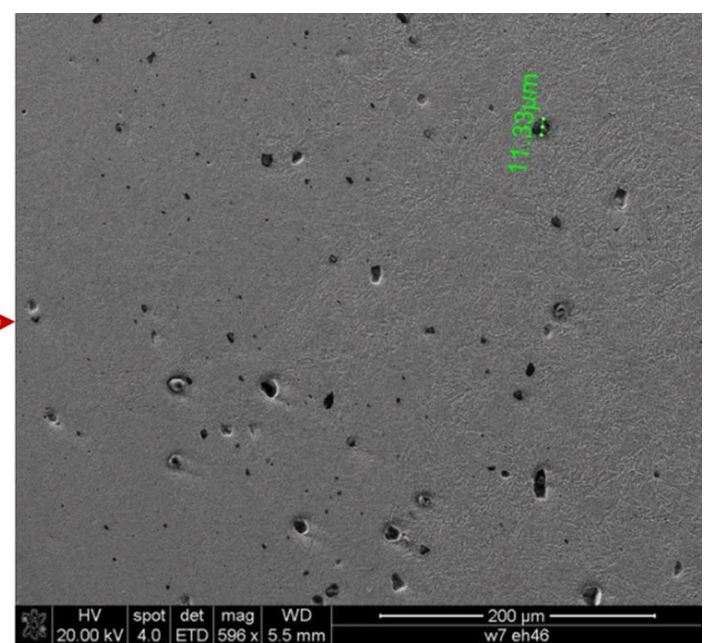

b

Fig. 11 SEM images of EH46 $\left(\mathrm{W}_{7 \mathrm{E}}\right)$ at plunge/dwell period showing BN particles (dark spots) with sizes ranging from 0.5 to $13 \mu \mathrm{m}$. (a) Low magnification (region under tool shoulder) and (b) high magnification

FSW $\mathrm{W}_{9 \mathrm{E}}$ at the top surface of the SZ and at the probe end, respectively.

SEM images of the top surface of SZ and in the probe end of $\mathrm{W}_{8 \mathrm{E}}$ and $\mathrm{W}_{9 \mathrm{E}}$ are shown in Figs. 19, 20, 21, and 22, respectively. Figure 23 is an SEM image with high magnification of $\mathrm{W}_{9 \mathrm{E}}$ at the probe end which shows BN particles. Table 10 shows the calculated percentage (\%) [11] of $\mathrm{BN}$ in a $1 \mathrm{~mm}^{2}$ scanned microstructure at the middle top of the $\mathrm{SZ}$ and at the probe end of samples $\mathrm{W}_{8 \mathrm{E}}$ and $\mathrm{W}_{9 \mathrm{E}}$. Figure 24 shows the $\mathrm{XRD}$ of samples $\mathrm{W}_{8 \mathrm{E}}$ and $\mathrm{W}_{9 \mathrm{E}}$, respectively.

\section{Discussion}

\section{Tool Wear in FSW DH36 at High Tool Rotational/ Traverse Speeds}

SEM-EDS of FSW DH36 joint $\mathrm{W}_{2 \mathrm{D}}$ (550RPM, $400 \mathrm{~mm} /$ min) in Figs. 2 and 3 shows different sizes of BN particles in the SZ. Tool wear is expected to be a result of the parent material resistance to the thermomechanical process that is friction stir welding. Although the tool torque for sample $\mathrm{W}_{1 \mathrm{D}}$ (Table 5) was higher than that of $\mathrm{W}_{2 \mathrm{D}}$, it did not show 


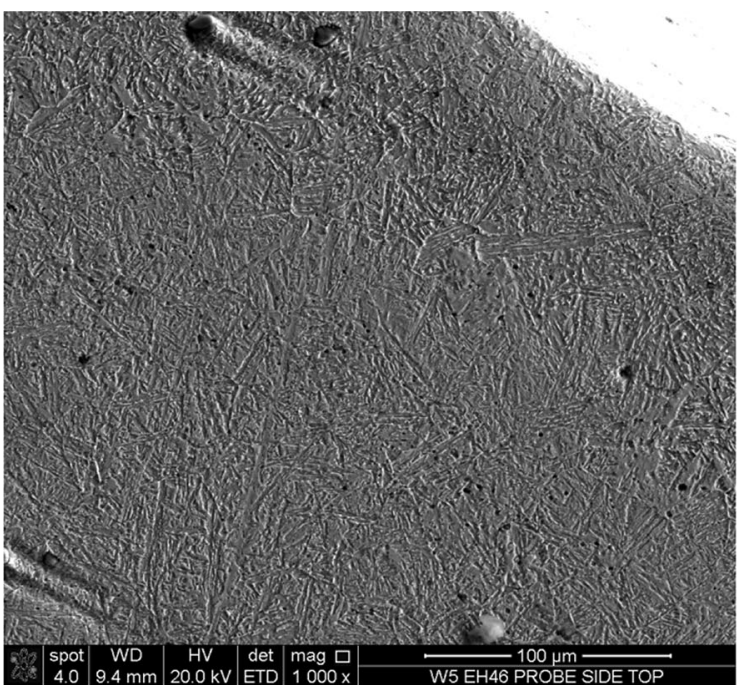

a

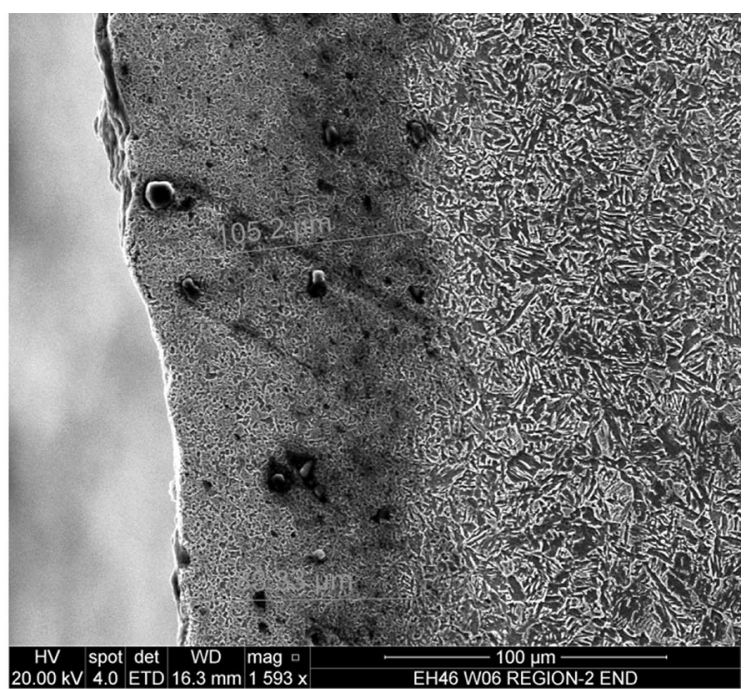

b

Fig. 12 EH46 at plunge/dwell period, probe side bottom (region-2 bottom), (a) $\mathrm{W}_{2 \mathrm{E}}$ and (b) $\mathrm{W}_{6 \mathrm{E}}$

Fig. 13 XRD scan of FSW of grade EH46 steel (plunge cases from $\mathrm{W}_{1 \mathrm{E}}-\mathrm{W}_{7 \mathrm{E}}$ at region 1 under the shoulder). The microstructure is mainly ferrite phase. $\mathrm{BN}$ peaks are presented

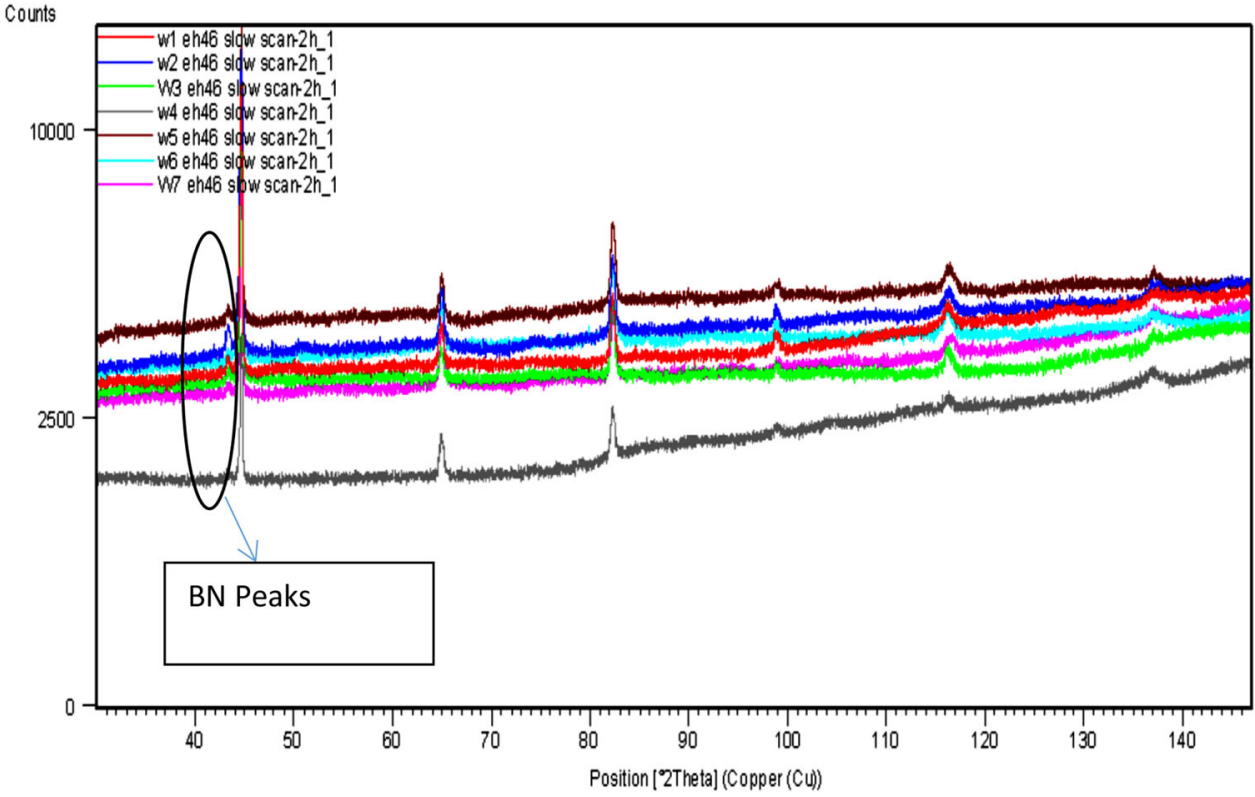

Table 8 The welding conditions and resulting IFM measurements of the plunge depth and areas of the various affected zones for samples $\mathrm{W}_{1 \mathrm{E}^{-}}$ $\mathrm{W}_{7 \mathrm{E}}$ EH46 steel

\begin{tabular}{|c|c|c|c|c|c|c|c|c|c|}
\hline $\begin{array}{l}\text { Weld } \\
\text { no. }\end{array}$ & $\begin{array}{l}\text { Tool rotational speed } \\
\omega(\mathrm{RPM}) \text { at } \\
\text { maximum plunge } \\
\text { depth }\end{array}$ & $\begin{array}{l}\text { Max. } \\
\text { plunge } \\
\text { force }\left(F_{z}\right) \\
\mathrm{KN}\end{array}$ & $\begin{array}{l}\text { Max. } \\
\text { traverse } \\
\text { force }\left(F_{x}\right) \\
\mathrm{KN}\end{array}$ & $\begin{array}{l}\text { Max. } \\
\text { torque } \\
(M) \mathrm{N} \mathrm{m}\end{array}$ & $\begin{array}{l}\text { Plunge } \\
\text { depth } \\
\text { (Z) mm } \\
\text { (IFM) }\end{array}$ & $\begin{array}{l}\text { Time }(t) \text { sec at } \\
\text { (dwelling) } \\
\text { plunge period }\end{array}$ & $\begin{array}{l}\text { Total TMAZ } \\
\text { (region } 1+2) \\
\text { area } \mathrm{mm}^{2}(\text { IFM) }\end{array}$ & $\begin{array}{l}\text { (Region 3) } \\
\text { IHAZ } \\
\text { mm }^{2} \\
\text { (IFM) }\end{array}$ & $\begin{array}{l}\text { (Region 4) } \\
\text { OHAZ } \\
\mathrm{mm}^{2} \\
\text { (IFM) }\end{array}$ \\
\hline $\mathrm{W}_{1 \mathrm{E}}$ & 200 & 157 & 17 & 498 & 11.05 & 6 & 47.46 & 64.7 & 82 \\
\hline $\mathrm{W}_{2 \mathrm{E}}$ & 200 & 127 & 17 & 471 & 11.43 & 8 & 67.5 & 78.5 & 102 \\
\hline $\mathrm{W}_{3 \mathrm{E}}$ & 120 & 116 & 21 & 598 & 11.56 & 7 & 58 & 69.6 & 112.6 \\
\hline $\mathrm{W}_{4 \mathrm{E}}$ & 120 & 126 & 20 & 549 & 11.47 & 6 & 66 & 64.25 & 118 \\
\hline $\mathrm{W}_{5 \mathrm{E}}$ & 120 & 115 & 17 & 532 & 11.47 & 7 & 55 & 93.5 & 120.4 \\
\hline $\mathrm{W}_{6 \mathrm{E}}$ & 120 & 105 & 18 & 583 & 11.78 & 7 & 68 & 99.5 & 143.8 \\
\hline $\mathrm{W}_{7 \mathrm{E}}$ & 120 & 119 & 20 & 548 & 11.57 & 7 & 57.2 & 91 & 120 \\
\hline
\end{tabular}


Table 9 BN percentage (\%) in EH46 plunge period at shoulder/probe side region, the scanned area is $1 \mathrm{~mm}^{2}$

\begin{tabular}{llllllll}
\hline Weld no. & $\mathrm{W}_{1 \mathrm{E}}$ & $\mathrm{W}_{2 \mathrm{E}}$ & $\mathrm{W}_{3 \mathrm{E}}$ & $\mathrm{W}_{4 \mathrm{E}}$ & $\mathrm{W}_{5 \mathrm{E}}$ & $\mathrm{W}_{6 \mathrm{E}}$ & $\mathrm{W}_{7 \mathrm{E}}$ \\
\hline BN\% & 1.4 & 2.8 & 0.65 & 0.7 & 0.9 & 3.3 & 1.2 \\
\hline
\end{tabular}

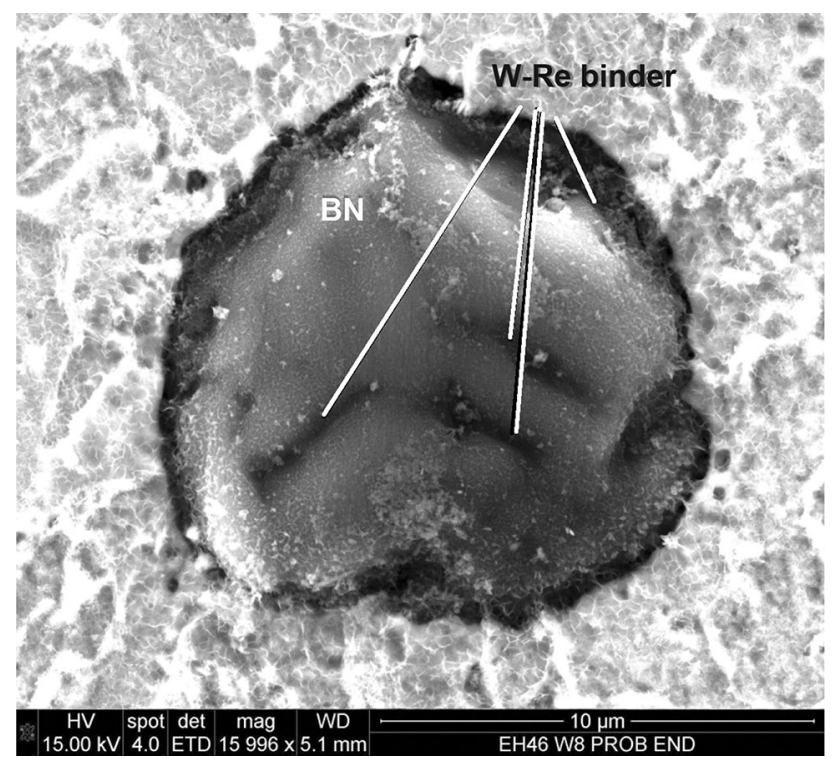

Fig. 14 Large BN particle in the top of SZ of FSW EH46 $\left(\mathrm{W}_{8 \mathrm{E}}\right)$

significant evidence of $\mathrm{BN}$ particles in the microstructure [as revealed by X-ray diffraction, Fig. $4 \mathrm{a}$ and $\mathrm{b}$ ]. The W-Re binder softening [8] as a result of temperature increase coming from the increase in tool rotational speed is most likely to be the reason for the higher \% of $\mathrm{BN}$ and therefore the higher PCBN tool wear in sample $\mathrm{W}_{2 \mathrm{D}}$ rather than in $\mathrm{W}_{1 \mathrm{D}}$. Also the higher traverse speed of the FSW tool in
$\mathrm{W}_{2 \mathrm{D}}$ accompanied with higher-temperature generation can exacerbate the tool wear, leading to a disastrous damage of the FSW tool. The top surface of the SZ as shown in Fig. 3 showed the highest presence of BN particles. These results are in agreement with the published work [12] in which it was found from modeling of the FSW of DH36 that the maximum temperature can approach the melting point of DH36 steel $\left(1450{ }^{\circ} \mathrm{C}\right)$ when applying tool speeds of $550 \mathrm{RPM} / 400 \mathrm{~mm} / \mathrm{min}$. W-25Re hardness was found in previous work to reduce by about $50 \%$ when the temperature increases from room temperature to $1450{ }^{\circ} \mathrm{C}$ [8].

\section{Tool Wear in FSW EH46 W1-W7 Plunge/Dwell Cases}

Figures 5, 6, 7, 8, 9, 10, and 11 are SEM images (low and high magnification) of samples $\mathrm{W}_{1 \mathrm{E}}-\mathrm{W}_{7 \mathrm{E}}$ plunge/dwell cases, respectively. The images are taken from the shoulder-probe region and show the different sizes and amounts of $\mathrm{BN}$ particles present. BN particles sizes were detected between 0.5 and $13 \mu \mathrm{m}$, and the percentage (\%) of BN was calculated [11] and is reported in Tables 9 and 10. Depending on the welding conditions and the calculated results of TMAZ size and plunge depth mentioned in Table 8 , the calculated percentage $(\%)$ of BN particles have varied as shown in Table 9. Sample $\mathrm{W}_{6 \mathrm{E}}$ showed the maximum percentage $(\%)$ of $\mathrm{BN}$ in the shoulder-probe region as a result of maximum plunge depth and TMAZ size. $\mathrm{W}_{3 \mathrm{E}}, \mathrm{W}_{4 \mathrm{E}}, \mathrm{W}_{5 \mathrm{E}}$, and $\mathrm{W}_{7 \mathrm{E}}$ have shown the lowest values of $\mathrm{BN}$ particles which can be attributed to the low tool rotational speed and also low plunge depth. $\mathrm{W}_{2 \mathrm{E}}$ also showed a higher $\%$ of $\mathrm{BN}$ in the shoulder-probe region compared to $\mathrm{W}_{1 \mathrm{E}}$ which may be a result of the higher plunge depth despite the fact that the same tool rotational
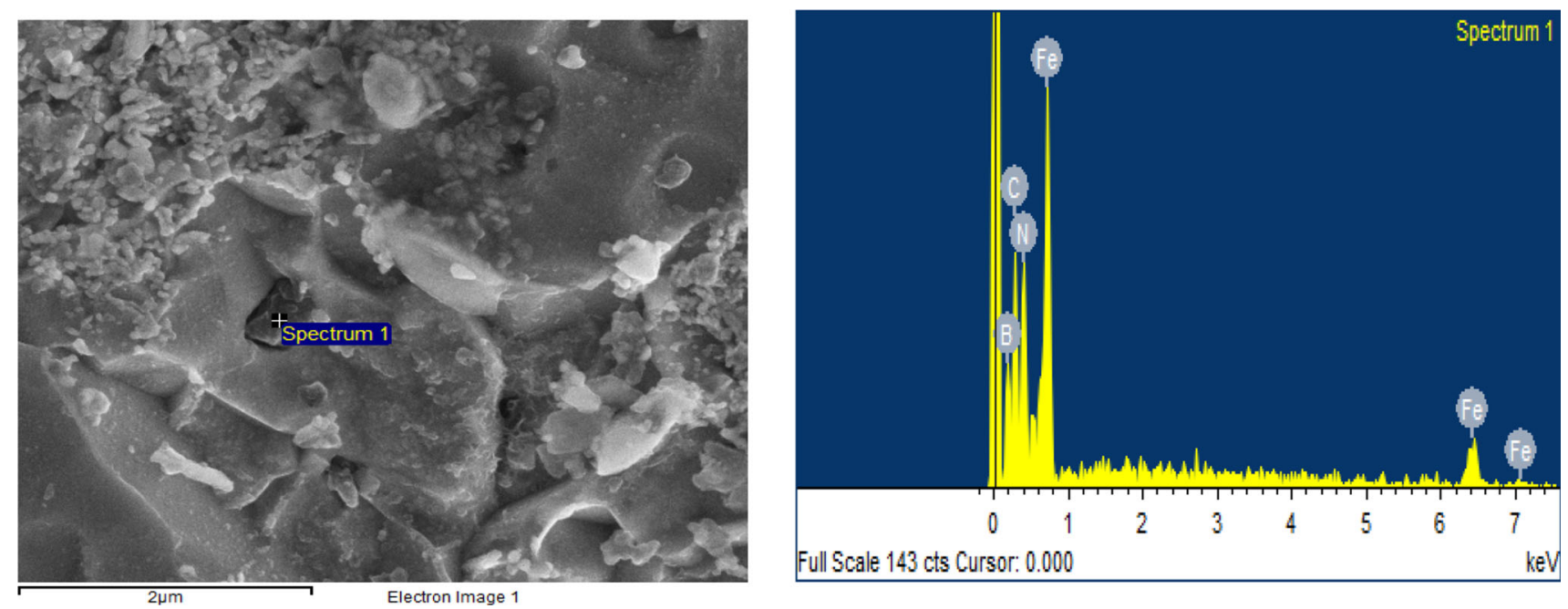

Fig. $15 \mathrm{BN}$ particles with different sizes at the top of SZ of FSW EH46 $\left(\mathrm{W}_{8 \mathrm{E}}\right)$ 

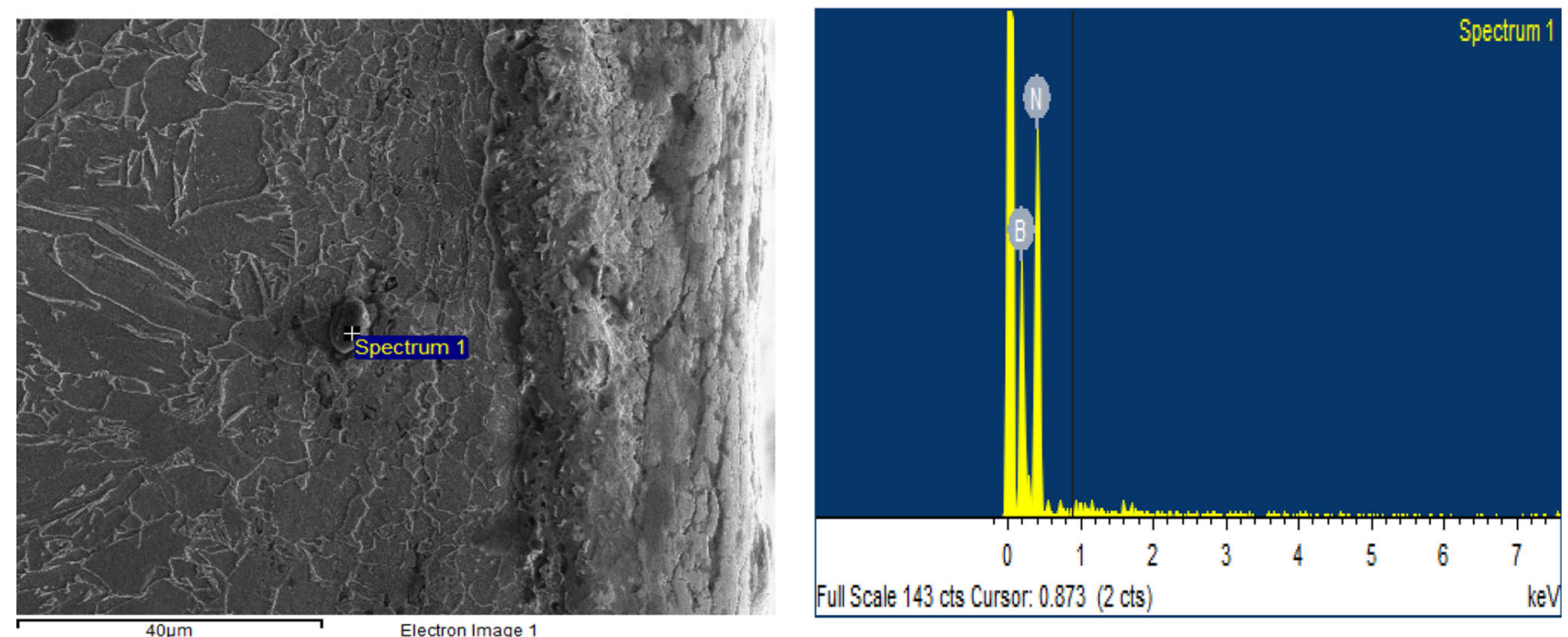

Fig. $160.5-\mu \mathrm{m}$ BN particle at the probe end of FSW EH46 $\left(\mathrm{W}_{8 \mathrm{E}}\right)$
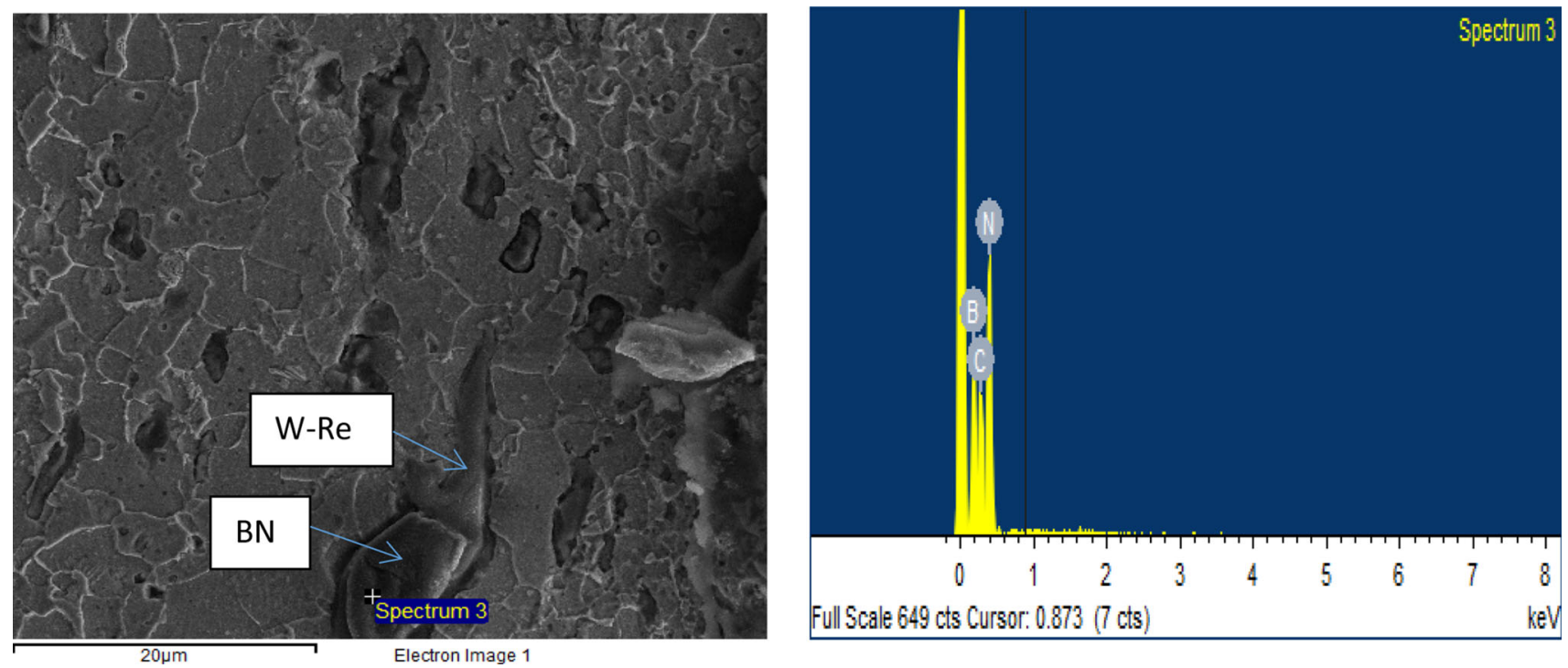

Fig. 17 Top surface of the SZ (steady state) showing evidence of different sizes of BN particle (EH46 $\left.\mathrm{W}_{9 \mathrm{E}}\right)$

speeds were applied. The $\% \mathrm{BN}$ in sample $\mathrm{W}_{2 \mathrm{E}}$ was also higher than $\mathrm{W}_{3 \mathrm{E}}, \mathrm{W}_{4 \mathrm{E}}, \mathrm{W}_{5 \mathrm{E}}$, and $\mathrm{W}_{7 \mathrm{E}}$ which have almost the same plunge depth as $\mathrm{W}_{2 \mathrm{E}}$. This finding can be attributed to the higher tool rotational speed of $\mathrm{W}_{2 \mathrm{E}}$ which in turn can cause an increase in the temperature at the tool/workpiece contact region, and thus, greater softening of the W-Re binder can be expected. Figure 12a and b is SEM images of the probe side bottom of sample $\mathrm{W}_{2 \mathrm{E}}$ and $\mathrm{W}_{6 \mathrm{E}}$, respectively, which show significant $\%$ of $\mathrm{BN}$ particles, particularly in $\mathrm{W}_{6 \mathrm{E}}$ and less in $\mathrm{W}_{2 \mathrm{E}}$. The higher plunge depth in $\mathrm{W}_{6 \mathrm{E}}$ may be the reason for this increase in tool wear. The XRD result (Fig. 13) shows ferrite and BN peaks, but no phase change in the microstructure or no recrystallization of the cubic $\mathrm{BN}$ has occurred.

\section{Tool Wear in FSW EH46 W $_{8 \mathrm{E}}$ and $\mathrm{W}_{9 \mathrm{E}}$ FSW Steady State}

Figure 14 is an SEM image with high magnification which shows a 13- $\mu \mathrm{m}$ BN particle in the SZ of FSW of $\mathrm{W}_{8 \mathrm{E}}$ joint; the binder of W-Re was also detected by SEM-EDS and is also shown. Softening of the binder accompanied by mechanical action (tool rotational/traverse speeds) may be the reason for the separation of the $\mathrm{BN}$ particles from the 

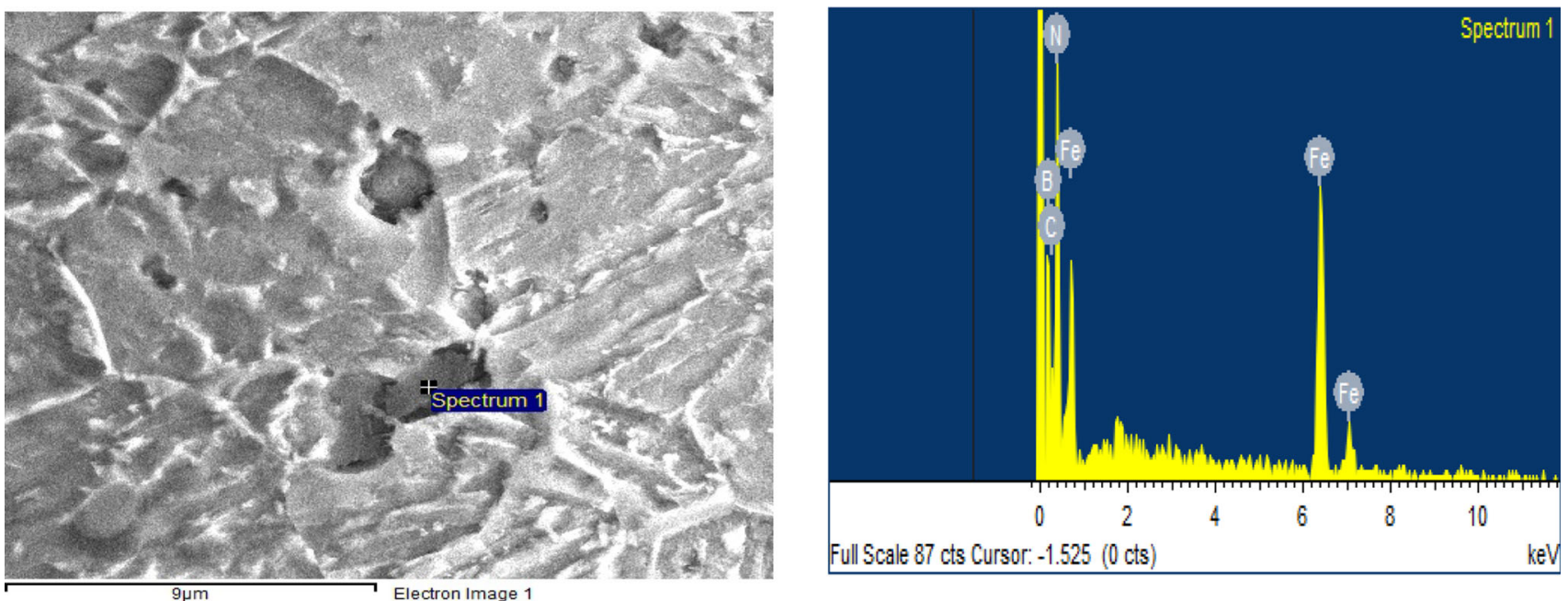

Fig. 18 Evidence of BN particle in SZ of the probe end region of FSW EH46 ( $\left.\mathrm{W}_{9 \mathrm{E}}\right)$

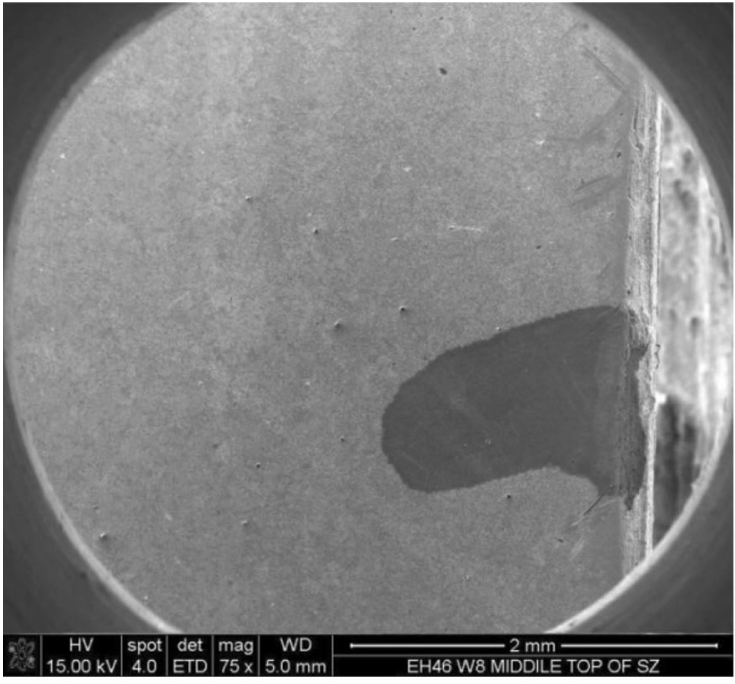

a

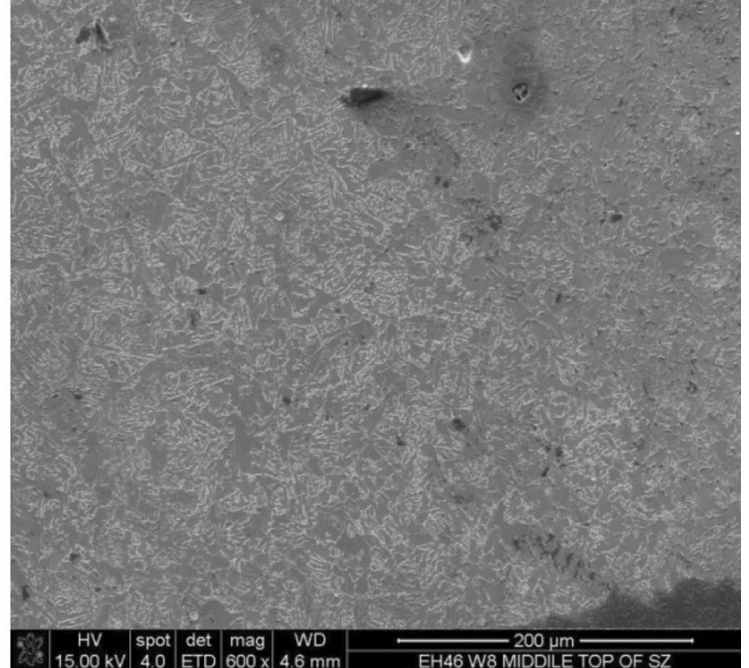

b

Fig. 19 Top center of SZ of EH46 $\mathrm{W}_{8 \mathrm{E}}$ (steady state), showing evidence of BN particles, (a) low magnification and (b) high magnification (etched in 2\% nital)

PCBN FSW tool which is then followed by those released particles becoming attached and entrapped in the SZ microstructure of the workpiece during the FSW process. Figures 15 and 16 show the SEM-EDS scanning (spot analysis) of BN in a FSW of sample EH46 $\mathrm{W}_{8 \mathrm{E}}$ at the top surface of the SZ and at the probe end, respectively. Figures 17 and 18 show the SEM-EDS of BN in the SZ of FSW EH46 sample $\mathrm{W}_{9 \mathrm{E}}$ at the top surface of the SZ and at the probe end, respectively. More BN particles were shown in sample $\mathrm{W}_{9 \mathrm{E}}$ at the top and bottom of the SZ rather than in sample $\mathrm{W}_{8 \mathrm{E}}$ which is the result of increasing the tool traverse speed from 50 to $100 \mathrm{~mm} / \mathrm{min}$. More SEM images of the top surface of SZ and in the probe end of samples $\mathrm{W}_{8 \mathrm{E}}$ and $\mathrm{W}_{9 \mathrm{E}}$ are shown in Figs. 20, 21, and 22, respectively. Figure 21a shows a significant amount of BN particles at the top surface of the $\mathrm{SZ}$ of sample $\mathrm{W}_{9 \mathrm{E}}$ until $250 \mu \mathrm{m}$ depth, whereas Fig. 21b is a higher-magnification SEM image of the SZ which shows BN particles surrounded by $\mathrm{W}-\mathrm{Re}$ binder (the darker color). The middle of the $\mathrm{SZ}$ of samples $\mathrm{W}_{8 \mathrm{E}}$ and $\mathrm{W}_{9 \mathrm{E}}$ did not show a significant presence of $\mathrm{BN}$ as shown in Figs. 20a and 22a, respectively, whereas BN at the probe end of both welds is clearly evident in Figs. 20b and 22b. The significant existence of $\mathrm{BN}$ in the top and bottom of the SZ but less in the middle 


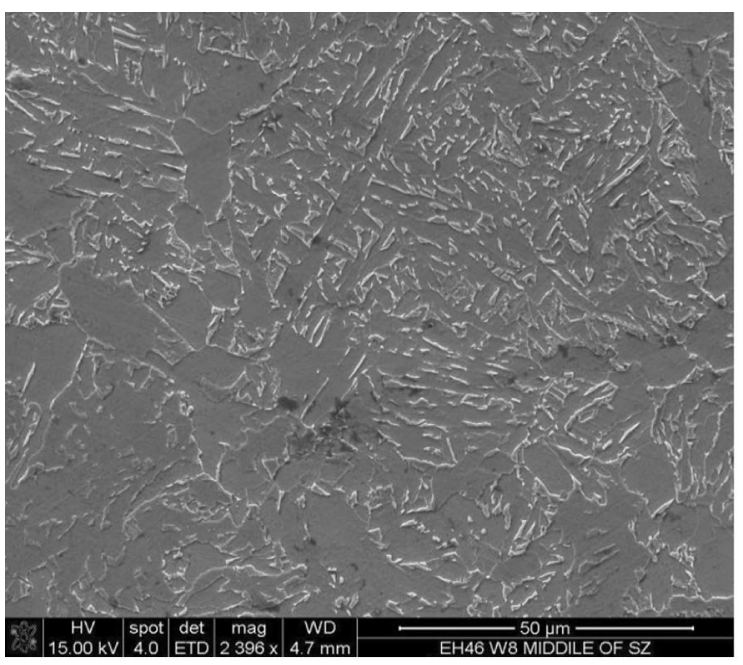

$\mathbf{a}$

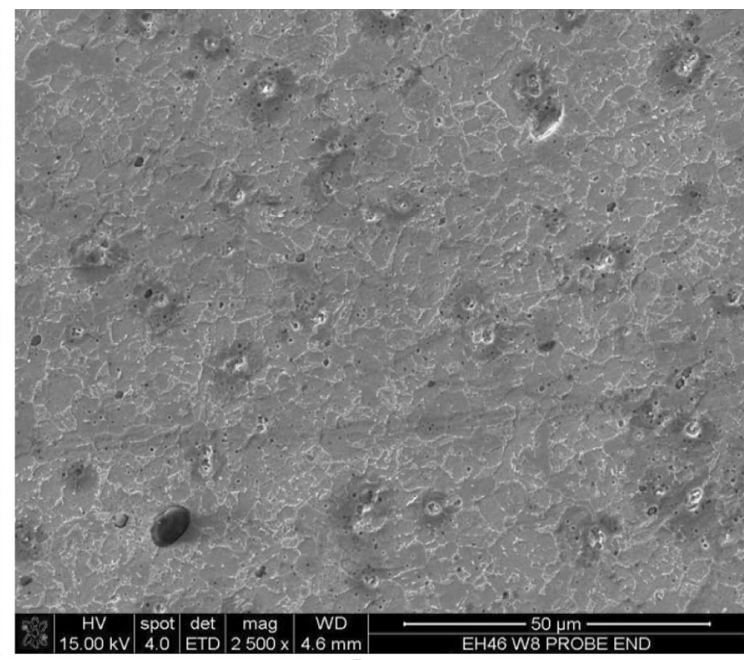

b

Fig. 20 EH46 $\mathrm{W}_{8 \mathrm{E}}$ (steady state). (a) The middle of SZ (no BN particles), microstructure is mainly acicular ferrite, (b) probe end SZ (BN particles are present), microstructure is mainly granular ferrite and some short plated cementite

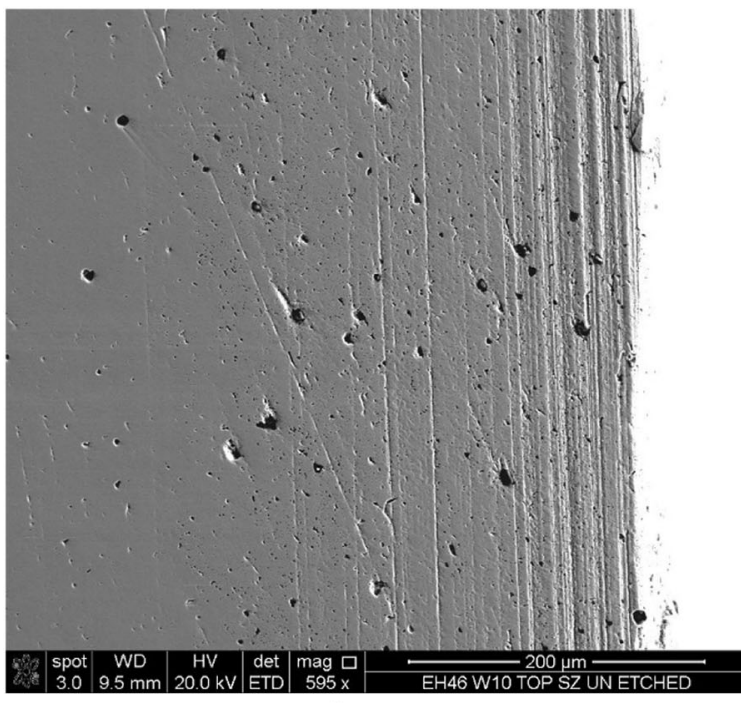

$\mathbf{a}$

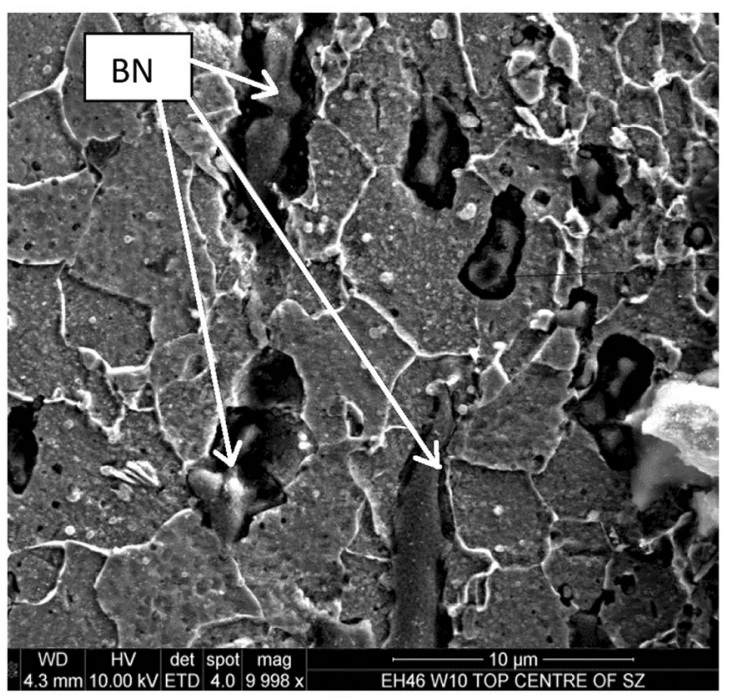

b

Fig. 21 Top middle center of SZ of EH46 $\mathrm{W}_{9 \mathrm{E}}$ (steady state) showing evidence of BN particles, (a) low magnification (un-etched) and (b) high magnification (etched)

of the SZ can be attributed to the fact that tool edge (top and bottom) is the most vulnerable locations with regard to wear as a result of experiencing higher temperatures or higher shear stress. Al-Moussawi et al. [12] showed by simulation that the tool shoulder periphery has experienced the maximum peak temperature on the advancing-trailing side and the maximum shear stress was on the leadingretreating side. They also showed that at higher traverse speeds, the maximum value of shear stress was at the shoulder periphery and probe end. This can be seen in Fig. 23 where BN particles are found at the probe end of sample $\mathrm{W}_{9 \mathrm{E}}$ as a result of higher traverse speed. Table 10 shows the calculated percentage $(\%)$ of $\mathrm{BN}$ in a $1 \mathrm{~mm}^{2}$ at the middle top of the SZ and at the probe end of samples $\mathrm{W}_{8 \mathrm{E}}$ and $\mathrm{W}_{9 \mathrm{E}}$. Wear of the FSW tool at the tool shoulder periphery in $\mathrm{W}_{9 \mathrm{E}}$ is about 3 times that in sample $\mathrm{W}_{8 \mathrm{E}}$, whereas, at the probe end it is approximately double. This finding is supported by the XRD analysis shown in Fig. 24 


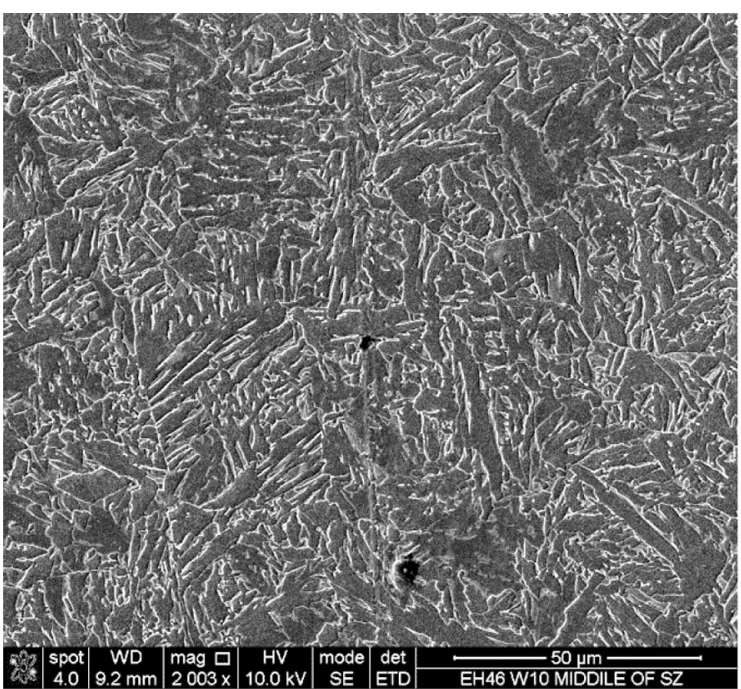

a

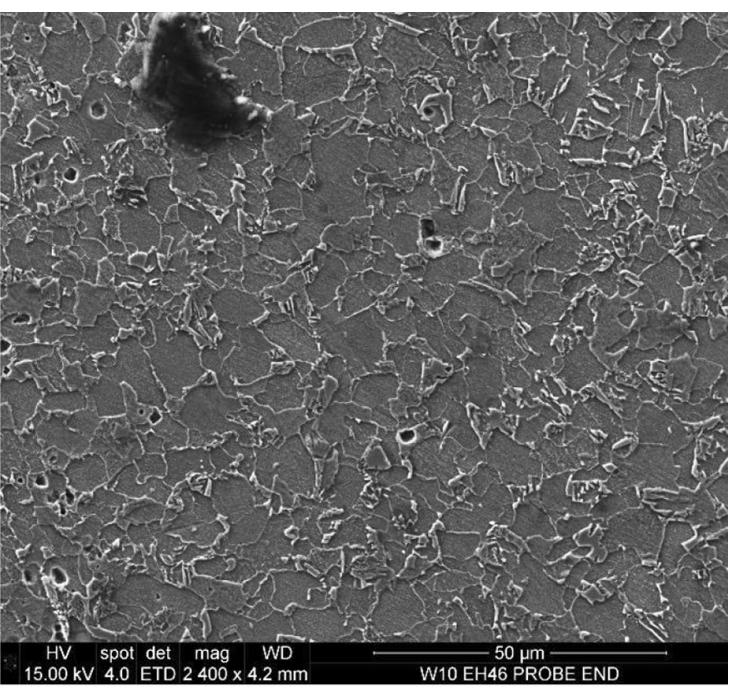

b

Fig. $22 \mathrm{EH}_{4} \mathrm{~W}_{9 \mathrm{E}}$ (steady state). (a) The middle of SZ (no BN particles), microstructure is mainly acicular ferrite, (b) probe end (BN particles are evident), the microstructure is mainly granular ferrite and cementite

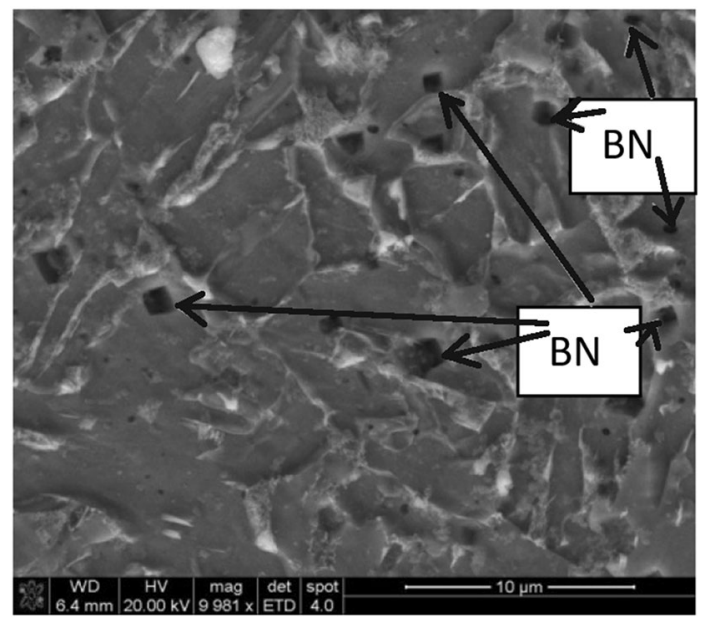

Fig. 23 High-magnification SEM image of sample $\mathrm{W}_{9 \mathrm{E}}(\mathrm{EH} 46)$ (steady state) at the probe end showing BN particles

Table 10 BN percentage (\%) in EH46 steady-state of samples $\mathrm{W}_{8 \mathrm{E}}$ and $\mathrm{W}_{9 \mathrm{E}}$ at the middle top of $\mathrm{SZ}$ and at the probe end, the scanned area is $1 \mathrm{~mm}^{2}$

\begin{tabular}{lllll}
\hline $\begin{array}{l}\text { Weld no. and } \\
\text { region }\end{array}$ & $\begin{array}{l}\mathrm{W}_{8 \mathrm{E}} \text { top } \\
\mathrm{SZ}\end{array}$ & $\begin{array}{l}\mathrm{W}_{8 \mathrm{E}} \text { probe } \\
\text { end }\end{array}$ & $\begin{array}{l}\mathrm{W}_{9 \mathrm{E}} \text { top } \\
\mathrm{SZ}\end{array}$ & $\begin{array}{l}\mathrm{W}_{9 \mathrm{E}} \text { probe } \\
\text { end }\end{array}$ \\
\hline $\mathrm{BN} \%$ & 1.1 & 1.3 & 4.4 & 2.8 \\
\hline
\end{tabular}

taken from the middle top of the SZ which shows that the peak associated with $\mathrm{BN}$ in sample $\mathrm{W}_{9 \mathrm{E}}$ is stronger than in sample $\mathrm{W}_{8 \mathrm{E}}$.

\section{Conclusion}

From the work carried out the following can be concluded:

- PCBN FSW tool wear has been found to increase with an increasing tool rotational speed as a result of W-Re binder softening. The top of the SZ and the weld root regions have showed the maximum presence of $\mathrm{BN}$ particles which indicates that the shoulder and probe end are the most affected tool parts for wear as a result of the thermomechanical effect.

- Increasing the plunge depth is associated with an increase in tool wear as a result of the increase in the surface contact area which in turn raises the temperature in the tool/workpiece contact region.

- Increasing the tool traverse speed has resulted in an increase in tool wear especially at the tool shoulder periphery. The increase in the value of shear stress on the tool surface was the main reason of this wear.

- The current study represents a step change in understanding the PCBN tool wear during the FSW process. Tool wear can be reduced by choosing the 
Fig. 24 XRD scan of FSW of EH46 grade (comparison between $\mathrm{W}_{8 \mathrm{E}}$ and $\mathrm{W}_{9 \mathrm{E}}$ at the top of $\mathrm{SZ}, \mathrm{W}_{9 \mathrm{E}}$ shows a stronger peak of $\mathrm{BN}$ than $\mathrm{W}_{8 \mathrm{E}}, \mathrm{Cu}$ $\mathrm{X}$-ray-tube)

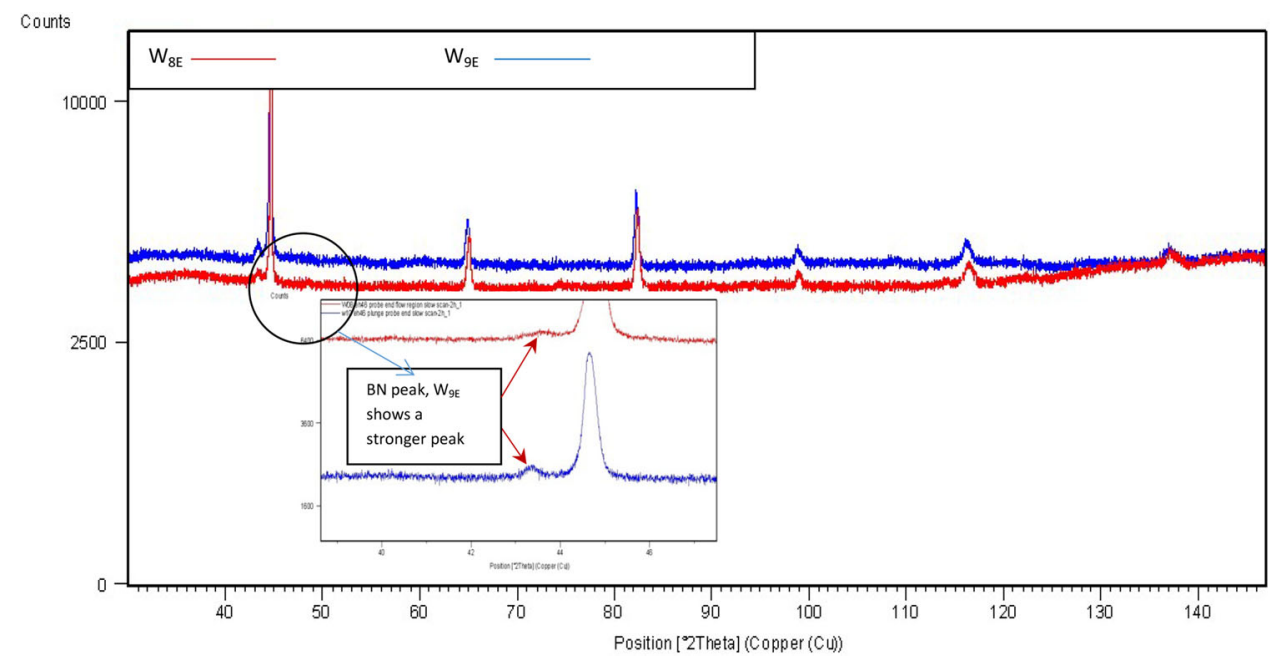

suitable combination of tool rotational/traverse speeds and plunge depth.

Acknowledgments The authors would like to thank the Ministry Of Higher Education, Iraq, for funding this project. Thanks are also due to The Welding Institute (TWI) for providing the friction welded samples and processing data.

Open Access This article is distributed under the terms of the Creative Commons Attribution 4.0 International License (http://creative commons.org/licenses/by/4.0/), which permits unrestricted use, distribution, and reproduction in any medium, provided you give appropriate credit to the original author(s) and the source, provide a link to the Creative Commons license, and indicate if changes were made.

\section{References}

1. R.S. Mishra, Z.Y. Ma, Friction stir welding and processing. Mater Sci Eng R Rep 50(1-2), 1-78 (2005)

2. Megastir. Friction stir welding of high melting temperature materials (2013). http://megastir.com/products/tools/fsw_tool. aspxpdf

3. R. Rai, A. De, H.K.D.H. Bhadeshia, T. DebRoy, Review: friction stir welding tools. Sci. Technol. Weld. Joining 16(4), 325-342 (2011)
4. J.M. Seaman, B. Thompson, Challenges of friction stir welding of thick-section steel, in Proceedings of the Twenty-first, 2011, International Offshore and Polar Engineering Conference, Maui, Hawaii, USA, June 19-24, 2011

5. P.J. Konkol, M.F. Mruczek, Comparison of friction stir weldments and submerged arc weldments in HSLA-65 steel. Suppl. Weld. J. 86, 187-195 (2007)

6. J. Perrett, J. Martin, J. Peterson, R. Steel, S. Packer, Friction stir welding of industrial steels. in Paper Presented at TMS Annual Meeting 2011. 27 Feb.-3 March 2011, San Diego, CA., USA

7. C.D. Sorensen, T.W. Nelson, Friction Stir Welding of Ferrous and Nickel Alloys (Materials Park, ASM International, 2007), pp. 111-121

8. M.L. Ramalingam, D.L. Jacobson, Elevated temperature softening of progressively annealed and sintered W-Re alloys. J. Less Common Metals 123, 153-167 (1986)

9. R.M. Hooper, J.I. Shakib, C.A. Brookes, Microstructure and wear of TiC cubic BN tools. Mater. Sci. Eng., A A106, 429-433 (1988)

10. Y. Zhang, Y.S. Sato, H. Kokawa, S.H.C. Park, S. Hirano, Stir zone microstructure of commercial purity titanium friction stir welded using pcBN tool. Mater. Sci. Eng., A A488(1-2), 25-30 (2008)

11. F.B. Pickering, The Basis of Quantitative Metallography (Institute of Metallurgical Technicians, London, 1976)

12. M. Al-Moussawi, A.J. Smith, A. Young, S. Cater, M. Faraji, Modelling of friction stir welding of DH36 steel. Int. J. Adv. Manuf. Technol. (2017). https://doi.org/10.1007/s00170-0170147-y 